\title{
Wrinkle layer and supracephalic attachment area: implications for ammonoid paleobiology
}

\author{
ALEKSANDR A. MIRONENKO
}

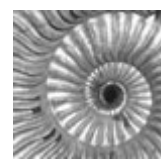

\begin{abstract}
In many planispiral ammonoid shells, the dorsal wrinkle layer is located not only inside the body chamber, but also protruded beyond the apertural edge, covering the part of the penultimate shell whorl in front of the aperture (similar to the black layer of Recent Nautilida). This external (relative to the body chamber) part of the wrinkle layer was rarely the focus of research and its implications for ammonoid paleobiology have not been studied in detail. This paper deals with this area found on the shells of seven genera of planispiral Jurassic (Callovian and Oxfordian) ammonites from Central Russia. The size and shape of this area as well as the surface structure of well-preserved specimens are described. The proposed name "supracephalic attachment area" (SCAA) represents the location and presumed biological significance of this part of the wrinkle layer. The implications of the existence of this area for the ammonoid mode of life, soft body structure and aperture orientation are discussed. The location of the part of the wrinkle layer outside of the body chamber proves that some part of the ammonoid soft body (likely the cephalic region) moved forward beyond the aperture during active swimming. This forces a review of calculations of ammonite aperture orientation which were based on the postulate that the soft body was located largely within the body chamber. $\bullet$ Key words: Ammonoidea, Jurassic, wrinkle layer, black layer, paleobiology, locomotion, soft-tissues.
\end{abstract}

MironenKo, A.A. 2015. Wrinkle layer and supracephalic attachment area: implications for ammonoid paleobiology. Bulletin of Geosciences 90(2), 389-416 (18 figures, 3 tables). Czech Geological Survey, Prague. ISSN 1214-1119. Manuscript received June 9, 2014; accepted in revised form January 19, 2015; published online March 5, 2015; issued March 23, 2015.

Aleksandr A. Mironenko, Kirovogradskaya st.28, 117519 Moscow, Russia; paleometro@gmail.com

The ammonoid wrinkle layer - a part of the shell with more or less prominent wrinkles on the surface - has been studied for more than 150 years. This organic-rich layer covers dorsal, ventral and lateral walls inside the ammonoid body chamber and forms part of the dorsal shell wall. It is well studied in different ammonoid genera (Quenstedt 1845-1849; Sandberger 1851; Merkt 1966; Nassichuk 1967; Walliser 1970; House 1971; Senior 1971; Tozer 1972; Bayer 1974; Kulicki 1979; Mapes 1979; Birkelund 1981; Doguzhaeva 1981; Zakharov \& Grabovskaya 1984; Korn 1985, 2000; Doguzhaeva \& Mutvei 1986, 1996; Keupp 2000; Kulicki et al. 2001; Klug et al. 2004; Korn et al. 2014). The part of the wrinkle layer, which extends from the body chamber and covers the surface of the penultimate whorl in front of the aperture in the tightly coiled planispiral ammonoid shells was also repeatedly described (Senior 1971, Tozer 1972, Birkelund 1981, Doguzhaeva 1981, Keupp 2000, Korn 2000, Kulicki et al. 2001, Klug et al. 2004). Most likely, the wrinkle layer in ammonoids was formed by both the mantle edge on the ventral and lateral sides of the aperture (Klug et al. 2007) and by the edge of the supracephalic mantle fold on the dorsal side (Kulicki et al. 2001). The wrinkle layer was found not only in Ammo- noidea, but also in Paleozoic Bactritida (Mapes 1979, Kröger et al. 2005) and Orthocerida (Teichert 1964, Kröger et al. 2005). This layer was also described in the body chambers of the representatives of the Silurian family Lechritrochoceratidae, which belongs to the order Barrandeocerida (Turek 1975). An unusually coarse wrinkle layer of Early Carboniferous ammonoids was recently described (Korn et al. 2014).

In the past, this layer was described under different names: "Runzelschicht" for the dorsal part of the layer and "Ritzstreifen" for lateral and ventral parts (Sandberger 1851, Walliser 1970, Bayer 1974, Korn 1985, Keupp 2000), as "black layer" (Klug 2004, Klug et al. 2004) and as "wrinkle layer" (Teichert 1964; Bayer 1974; Mapes 1979; Birkelund 1981; Zakharov \& Grabovskaya 1984; Doguzhaeva \& Mutvei 1986, 1996; Keupp 2000; Korn 2000; Kulicki et al. 2001; Kröger et al. 2005; Korn et al. 2014). The structure of this layer in different ammonoid genera significantly varies in terms of type and proportions of mineral and organic components (since this layer is partly mineralized) as well as in the size and shape of the wrinkles (Keupp 2000, Kulicki et al. 2001, Korn et al. 2014). In some cases, this layer is preserved as dark coating 
on the shell surface (the dark color may be caused by preserved melanin or it appeared diagenetically) without a wrinkled lamella (Birkelund 1981, Klug 2004, Klug et al. 2004). In other cases, the wrinkled surface can be preserved, but it may not necessarily be dark (Korn 2000, Korn et al. 2014), possibly due to the destruction of organic matter. Nevertheless, the term "wrinkle layer" is more universal and prevalent in palaeobiological literature and is used in this publication to designate this structure, even if the wrinkles on its surface were not found.

The function of the wrinkle layer was repeatedly discussed (see Keupp 2000), but the part of this layer, located outside of the body chamber on the surface of the previous shell whorl, was rarely the focus of research. Its microstructure was studied in detail in many ammonoids (Kulicki et al. 2001). This area was interpreted as a place of attachment of the supracephalic mantle fold (Kulicki et al. 2001, Klug et al. 2004) or additionally of the hood (Klug et al. 2004, Korn \& Klug 2012). However, its implications for ammonoid paleobiology and mode of life were only briefly touched on.

This paper deals with the outer (i.e. located outside of the body chamber) part of the wrinkle layer. The study is based on new materials of Middle and Upper Jurassic ammonites from Central Russia with well-preserved outer black layer and/or wrinkle layer areas (or their imprints) on the surface of the penultimate whorl. A comparison of the dimension of these areas among ammonites with different shell shapes and a calculation of the ratio of the area to the shell diameter showed regularities, which reveal a relationship between these structures and the ammonite's mode of life. Some assumptions about the importance of these areas for the swimming mechanism of ammonites and their maneuverability are proposed. The possibility of the presence of a Nautilus-like hood or other hood-like structures of the ammonoid soft-body is discussed. The location of the ammonite soft-body relative to the aperture during swimming is also discussed taking the presence of a soft-tissue attachment area in front of the body chamber into account.

\section{Material and methods}

The present study is based on 30 well-preserved ammonite shells from three localities in Central Russia (Fig. 1). These are quarries near Mikhailov in the Ryazan region (Middle Jurassic, Middle and Upper Callovian) (see Rogov 2004), the "Dubki" quarry in the Saratov region (Middle Jurassic, Upper Callovian) (Seltzer 1999, Rogov 2004, Larson 2007, Kiselev et al. 2013), and natural exposures at the Moscow riverbank near Markovo village in the Moscow region (Upper Oxfordian). All ammonite shells studied here had been collected between 2010 and 2013. They belong to five families and seven genera (Table 1).
In all investigated shells, phragmocones are preserved, but most of the body chambers were crushed or dissolved. However, the aperture position can be determined by remnants of the umbilical seam, which can be seen on the lateral surfaces of the preceding whorl. The phragmocones of all studied ammonites are filled by pyrite, but aragonitic shell layers are preserved.

The studied specimens were viewed at various angles under incident illumination with the naked eye and were examined with an optical microscope. Several specimens were examined under the scanning electronic microscope (SEM) TESCAN // VEGA with BSE detector in Paleontological institute of Russian Academy of Science (Moscow). Most of the studied specimens are deposited at the Moscow State University Museum (MSU), collection No. 115, two specimens (indicated by SPC) are hosted in a private collection of A. Homenko (Moscow, Russia).

\section{Terminology}

The part of the wrinkle layer which is located on the lateral and ventral sides inside the body chamber ("Ritzstreifen") is not discussed here. Therefore, the term "wrinkle layer" is used herein to denote the structure located only on the dorsal side.

The part of the wrinkle layer in front of the aperture outside of the body chamber on the surface of the penultimate whorl has been coined "supracephalic attachment area" (abbreviated SCAA). With this term, I want to stress the potential functional significance of this area. The term "outer component of the dorsal shell wall" introduced by Kulicki et al. (2001) is absolutely correct, but it could be misidentified with the outer layer of the shell wall and does not reflect the functional significance of this area. The term "black layer" which denotes the same structure in Nautilida is also not very useful because this area is not always dark in color on the observed ammonite shells. The common term "wrinkle layer" ("Runzelschicht") has a broader meaning since it describes a wrinkled surface of this layer, whereas on many studied shells, wrinkles are absent or disappeared by diagenesis and the surface of the area in front of aperture was primarily or became secondarily smooth. The term "supracephalic attachment area" is derived from the name of the supracephalic mantle fold, which likely was attached to this area (Kulicki et al. 2001, Klug et al. 2004). It reflects the location and presumable paleobiological significance of the outer (located outside of the body chamber) component of the wrinkle layer (Fig. 2). The ammonite aperture (more precisely the front end of the umbilical seam) has been assigned as the rear boundary of the SCAA, whereas the layer forming the SCAA continues into the body chamber on the surface of the previous whorl. 


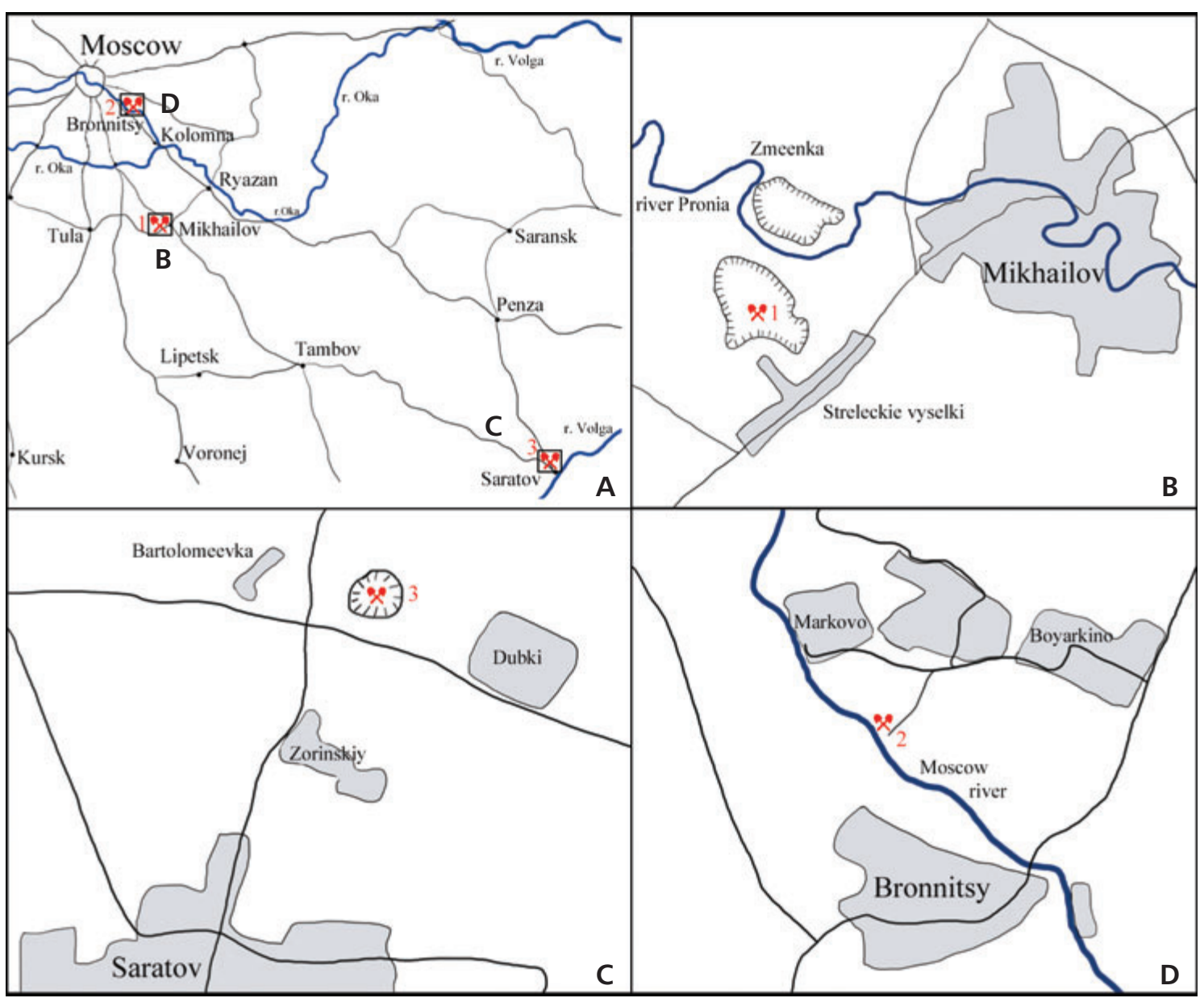

Figure 1. Locality maps (A-D). 1 - Mikhailov quarry in Ryazan region $\left(54^{\circ} 12^{\prime} 42.47^{\prime \prime} \mathrm{N} ; 38^{\circ} 57^{\prime} 8.58^{\prime \prime} \mathrm{E}\right), 2$ - river shore near Markovo village in the

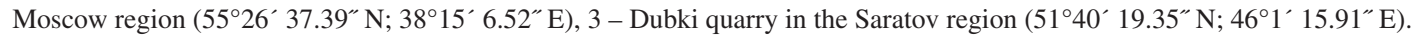

Table 1. Families and genera of studied ammonites.

\begin{tabular}{llll}
\hline Family & Genus & Age & Locality \\
\hline Cardioceratidae & Pseudocadoceras Buckman & Middle Jurassic, Upper Callovian & Mikhailov \\
& Quenstedtoceras Hyatt & Middle Jurassic, Uppermost Callovian & Dubki \\
& Amoeboceras (Hyatt) & Upper Jurassic, Upper Oxfordian & Markovo \\
Perisphinctidae & Binatisphinctes Buckman & Middle Jurassic, Middle Callovian & Mikhailov \\
Kosmoceratidae & Kosmoceras Waagen & Middle Jurassic, Middle Callovian & Mikhailov \\
Aspidoceratidae & Peltoceras Waagen & Middle Jurassic, Uppermost Callovian & Dubki \\
Oppeliidae & Sublunuloceras Spath & Middle Jurassic, Upper Callovian & Mikhailov \\
\hline
\end{tabular}

\section{Measurements}

The front end of the umbilical seam, which is seen in most of the studied specimens, is interpreted as the starting point of the SCAA (the apertural margin). In many ammonites, the wrinkle layer (or its imprint) is extended toward the umbilicus immediately after the front end of the umbilical seam (= aperture), which also helps to identify the end of the body chamber and the beginning of the SCAA (Fig. 2).
To compare the size of the supracephalic attachment area in studied ammonites, its angular length was measured (Table 2). However, a relatively short SCAA can be quite large if it is located on a shell with a wide ventral side, probably larger than the SCAA of a keeled oxyconic shell virtually devoid of a ventral surface. Therefore, a comparison of the area covered by the SCAA was made. For ammonites with a narrow venter and keel (Sublunuloceras, Pseudocadoceras, Quenstedtoceras, Amoeboceras), the area was roughly calculated as twice the area of a trapezoid 


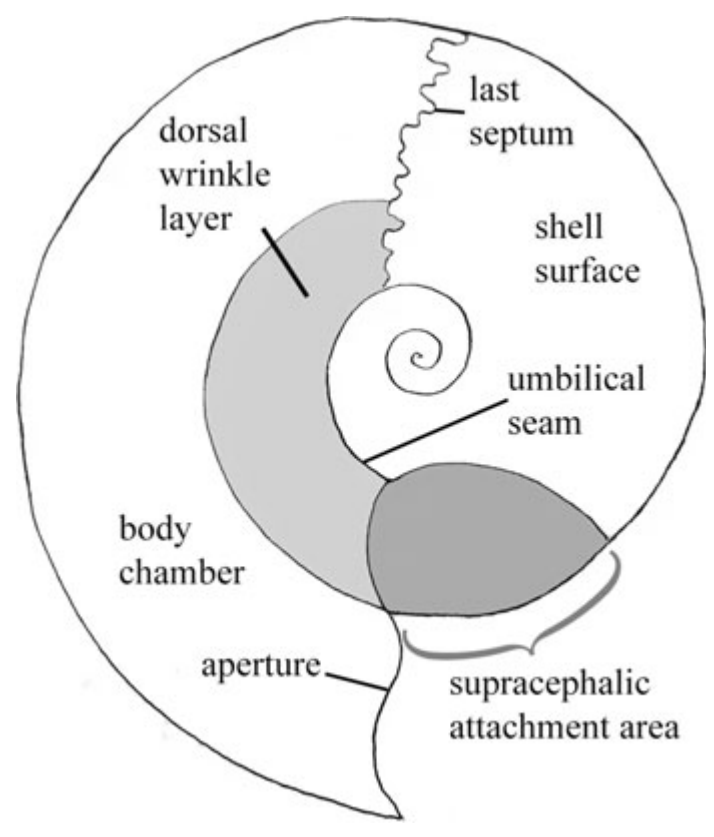

Figure 2. Scheme of the position of the dorsal wrinkle layer and supracephalic attachment area in front of the aperture. The body chamber wall is shown as a transparent.

comprising the majority of the SCAA on the flanks (Fig. 3A). For ammonites with a relatively wide venter (Binatishpinctes, Peltoceras), the SCAA was calculated as the area of the trapezoid covering most of the SCAA (Fig. 3B). For Kosmoceras shells with flat venter, the SCAA was calculated as the sum of the rectangle area for the venter and twice the area of a triangle for the flanks (Fig. 3C). I would like to stress here that these values represent estimates and not exact values. The error of the calculation may occur during the determination of the SCAA boundaries. Moreover, the three-dimensionally distributed area of ornamentation such as ribs and spines as well as the curvature of the shell wall were not taken into account in these calculations. However, the main purpose of the calculations was not to obtain accurate data on the SCAA of every shell, but to obtain approximate values for a first comparison of these surfaces in the studied ammonite genera.

Since the SCAA depends on shell size, a ratio of this area to shell diameter was calculated (see Table 2). None of the shells studied herein has a fully preserved body chamber, but the preserved remnants of the umbilical seam on the surface of the phragmocone allowed for the use of formulas proposed by Raup $(1966,1967)$ to calculate the actual final diameter of the shell. Raup $(1966,1967)$ elaborated the following parameters describing the morphology of the planispiral shell: the shape of the generating curve (S), the whorl expansion rate (W), the position of the generating curve in relation to the coiling axis (D). The value of the parameters are calculated using the following formulas: $\mathrm{W}=(\mathrm{d} / \mathrm{e})^{2}, \mathrm{D}=\mathrm{c} / \mathrm{d}, \mathrm{S}=\mathrm{b} / \mathrm{a}(\operatorname{Raup} 1967$, text-fig. 1$)$. It is here assumed that the value of D is constant for each shell. The parameters of the majority of real ammonoid shells changed during ontogenesis, especially during the formation of the terminal body chamber, but in this case, these variations are neglected. Thus, I calculated D using the values measured on the preserved portion of the shell: $\mathrm{c}_{1}$ (the distance between the coiling axis and the umbilical wall) and $d_{1}$ (the distance between the coiling axis and the venter; Fig. 4) and then measure the value of $\mathrm{c}$ at the level of the aperture $\left(c_{a}\right)$. This will allow to calculate $d_{a}$ (the distance between the center of the shell coiling and ventral point of the aperture) using the formula $d_{a}=c_{a} / D$. The shell diameter is equal to $d_{a}+e_{a}$. If the lost fragment of the body chamber is less than half of a whorl, the value of $e_{a}$ can be measured (see Fig. 4), for the other shells, $e_{a}$ can be calculated by the same formula $\mathrm{d}=\mathrm{c} / \mathrm{D}$.

The author was not able to compare the ratio between supracephalic attachment areas and body-chamber lengths by the method proposed by Klug et al. (2004) because of shell preservation. In the majority of the examined specimens, it is difficult to determine the position of the last septum and measure the length of the body chamber. In some specimens, the pyritized part of the body chamber is partially preserved (Fig. 5) or nearly the entire body chamber, but flattened and without aperture (Fig. 6). In other cases, it is impossible to exclude that part of the septa had been destroyed together with the body chamber during fossilization and the currently preserved last septum is not really the last septum of the ammonite phragmocone (Fig. 7C, E).

\section{Results and description}

The SCAA has three types of preservation in the studied material. In the first case, it is just an imprint of the wrinkle layer. Its material is not preserved, but the external nacreous shell layer at the SCAA is different from the coloration of the rest of the shell surface. In the second case, the wrinkle layer has completely or partially been replaced by pyrite. It was observed in all the Sublunuloceras macroconchs and in one Quenstedtoceras microconch. In the third case, the wrinkle layer is preserved as a black or brown phosphatized coating on the surface of the penultimate whorl. In the second and third cases, the texture of the wrinkle layer surface is preserved. In the first case, only the shape of the SCAA is visible. Below, I describe the SCAAs of each studied genus in detail.

\section{Pseudocadoceras}

Pseudocadoceras (Figs 5, 6) is a microconch genus, which is characterized by relatively small discoconic shells. The wrinkle layer of the studied Pseudocadoceras specimens is 


\begin{tabular}{|c|c|c|c|c|c|}
\hline Taxon & Specimen No. & $\mathrm{L}\left({ }^{\circ}\right)$ & $\mathrm{D}(\mathrm{mm})$ & $\mathrm{S}\left(\mathrm{mm}^{2}\right)$ & $\mathrm{S} / \mathrm{D}$ \\
\hline Amoeboceras alternoides [m] & MSU 115/6 & 50 & 42.6 & 81 & 1.9 \\
\hline Amoeboceras alternoides [m] & MSU $115 / 8$ & 55 & 50.8 & 136.5 & 2.69 \\
\hline Amoeboceras alternoides [m] & MSU 115/14 & 50 & 45.2 & 67.5 & 1.49 \\
\hline Amoeboceras alternoides [m] & MSU 115/15 & 40 & 46.8 & 70 & 1.5 \\
\hline Amoeboceras alternoides [m] & MSU 115/16 & 45 & 46.5 & 74.25 & 1.6 \\
\hline Amoeboceras alternoides [m] & MSU 115/17 & 40 & 41 & 56 & 1.37 \\
\hline Amoeboceras alternoides [m] & MSU 115/19 & 55 & 42 & 84.5 & 2.01 \\
\hline Amoeboceras alternoides $[\mathrm{m}]$ & MSU 115/24 & 50 & 50.7 & 87.5 & 1.73 \\
\hline in average & & 48.13 & & & 1.78 \\
\hline Binatisphinctes sp. [m] & SPC $15 \mathrm{M}$ & 35 & 73.4 & 103.5 & 1.41 \\
\hline Binatisphinctes sp. $[\mathrm{M}]$ & SPC $112 \mathrm{M}$ & 20 & 238.4 & 470 & 1.97 \\
\hline in average & & 27,5 & & & 1.69 \\
\hline Pseudocadoceras sp. [m] & MSU 115/4 & 110 & 32.4 & 180 & 5.56 \\
\hline Pseudocadoceras sp. [m] & MSU 115/10 & 90 & 32 & 175.75 & 5.49 \\
\hline Pseudocadoceras sp. [m] & MSU 115/11 & 80 & 31 & 105 & 3.39 \\
\hline Pseudocadoceras sp. [m] & MSU 115/18 & 110 & 33 & 180.5 & 5.47 \\
\hline Pseudocadoceras sp. (juv) & MSU $115 / 22$ & 70 & 30 & 38.8 & 1.29 \\
\hline in average (for all specimens) & & 92 & & & 4.24 \\
\hline in average (without juvenile) & & 97.5 & & & 4.98 \\
\hline Quenstedtoceras lamberti $[\mathrm{m}]$ & MSU 115/1 & 55 & 75.9 & 372 & 4.9 \\
\hline Quenstedtoceras lamberti $[\mathrm{m}]$ & MSU 115/2 & 80 & 57.3 & 350.75 & 6.12 \\
\hline Quenstedtoceras cf. lamberti [m] & MSU 115/5 & 60 & 45.9 & 160 & 3.49 \\
\hline Quenstedtoceras cf. flexicostatum [m] & MSU 115/7 & 55 & 54 & 199.75 & 3.7 \\
\hline Quenstedtoceras lamberti $[\mathrm{m}]$ & MSU 115/20 & 70 & 37.4 & 120.25 & 3.22 \\
\hline Quenstedtoceras lamberti (juv) & MSU 115/28 & 50 & 36.8 & 75 & 2.04 \\
\hline in average (for all specimens) & & 61.67 & & & 3.91 \\
\hline in average (without juvenile) & & 64 & & & 4.28 \\
\hline Sublunuloceras lonsdalii $[\mathrm{M}]$ & MSU 115/3 & 70 & 141.3 & 850 & 6.02 \\
\hline Sublunuloceras lonsdalii $[\mathrm{M}]$ & MSU 115/21 & 70 & 145.71 & 975 & 6.69 \\
\hline Sublunuloceras lonsdalii $[\mathrm{M}]$ & MSU 115/25 & 70 & 149.5 & 969 & 6.48 \\
\hline in average & & 70 & & & 6.4 \\
\hline Peltoceras arduennense [m] & MSU $115 / 23$ & 25 & $80 *$ & 107.63 & 1.35 \\
\hline- & & & & & 1.35 \\
\hline Kosmoceras proniae $[\mathrm{m}]$ & MSU $115 / 27$ & 22 & 132.9 & 63.25 & 0.48 \\
\hline Kosmoceras proniae $[\mathrm{m}]$ & MSU 115/26 & 22 & 126 & 69 & 0.55 \\
\hline in average & & 22 & & & 0.51 \\
\hline
\end{tabular}

Table 2. Parameters of supracephalic attachment areas and shells of different ammonite genera. Abbreviations: L - angular length of the supracephalic attachment area; D - calculated initial shell diameter; $\mathrm{S}$ - area of the supracephalic attachment place; S/D - ratio of the area to initial shell diameter; $[\mathrm{m}]$ - microconchs, $[\mathrm{M}]$ - macroconchs; * marks that initial shell diameter of this shell fragment was calculated approximately by means of an analogy of the fully preserved specimens. dissolved and its structure lost, but the imprints of the SCAA are clearly visible. In one specimen (Fig. 5A), the black coloration of the SCAA is preserved. The two shells (Fig. 6) preserve their slightly flattened pyritized body chambers. Four specimens have long and large SCAAs with a width exceeding that of the aperture, whereas the smallest specimen (Fig. 5B), which probably died before maturation, has a relatively short and narrow SCAA. The average angular length of the Pseudocadoceras SCAA is almost $92^{\circ}$ (Table 2). This is the maximum value among the ammonites studied herein. The ratio of the SCAA to the calculated shell diameter ranges from 3.39 to 5.56 for adult shells of Pseudocadoceras (and is equal to 1.29 for a presumably immature specimen).

\section{Quenstedtoceras}

All studied Quenstedtoceras shells can be classified as microconchs which have keeled oxyconic shells with frequent and more or less smooth ribs (Fig. 7). In five Quenstedtoceras specimens, the wrinkle layer is not preserved, but its imprints are visible, allowing to measure the size of the SCAA (Fig. 7A, C-F). In only one case (Fig. 7B), the wrinkle layer surface is well-preserved. The SCAA on the five specimens is wider than the aperture, whereas in the one small specimen (Fig. 7D) which probably died before maturation, the SCAA does not exceed the width of the aperture.

The surface of the SCAA in the specimen with a preserved wrinkle layer (Fig. 7B) looks like a cobblestone road 

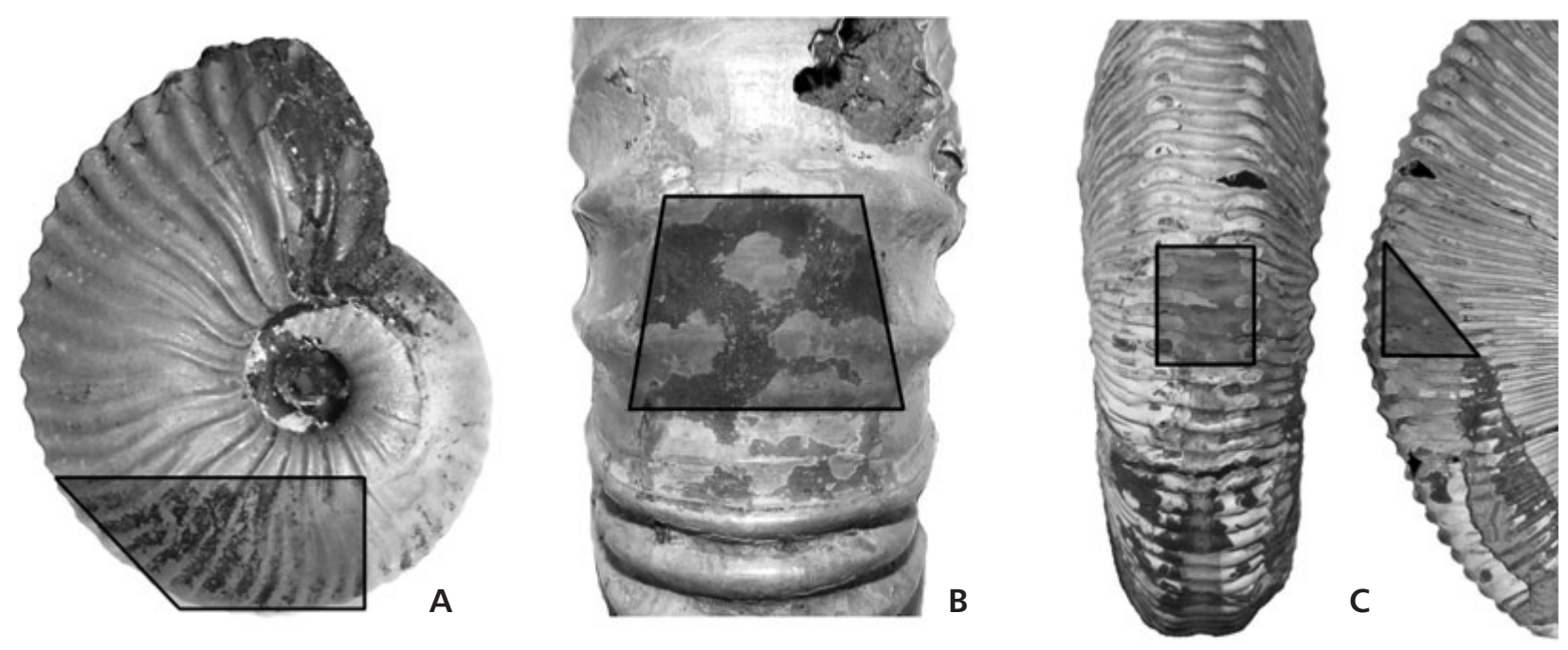

Figure 3. The scheme of calculation of the area of the SCAA. $\bullet$ A - calculation of the area in oxyconic and discoconic shells, B - in serpenticonic and platyconic shells with a rounded ventral side, $\mathrm{C}$ - in shells with a flattened ventral side.

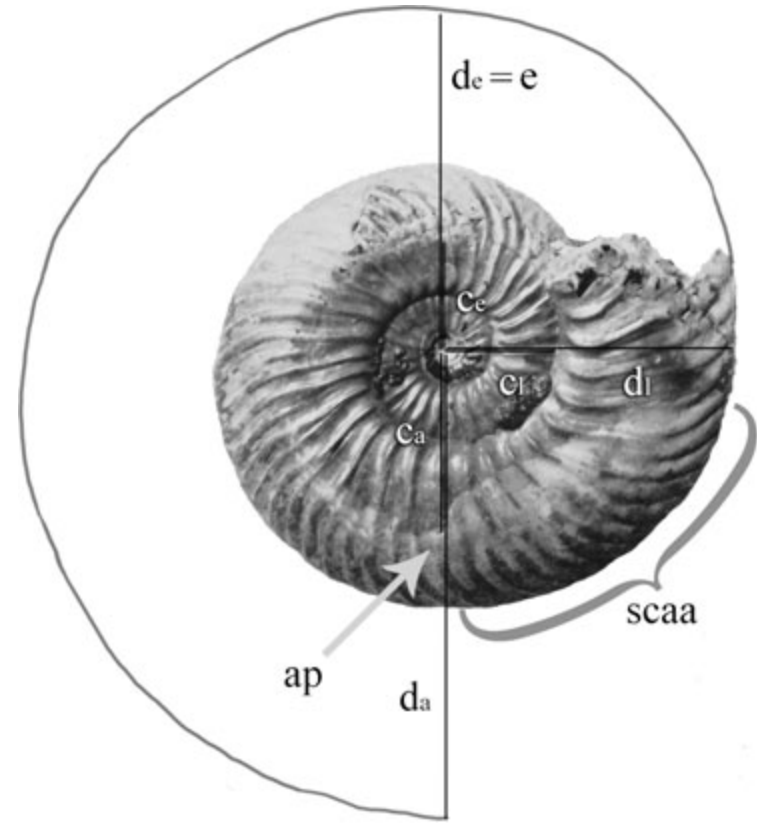

Figure 4. Scheme for the calculation of the initial shell diameter. The scheme is based on the Quenstedtoceras lamberti phragmocone (MSU $115 / 2)$. $~ c$ - the distance between the coiling axis and umbilical wall $(\mathrm{cl}-$ measured at the last preserved part of the last whorl; $\mathrm{ca}$-calculated at the aperture; ce-calculated or measured at a point opposite the aperture). $\cdot \mathrm{d}$ - the distance between the coiling axis and the venter $(\mathrm{dl}-$ measured at the last preserved part of the last whorl; da - calculated at the aperture; de - calculated or measured at a point opposite the aperture). $\bullet$ ap - position of the aperture, found by the end of the umbilical seam. • scaa supracephalic attachment area.

consisting of rounded elements (Figs 8A, 9A). The wrinkle layer and SCAA (as an "outer component of the dorsal shell") in Quenstedtoceras have been described previously (Kulicki 1979, Kulicki et al. 2001). However, the shape of the SCAA of this genus has not been described or depicted.
The angular length of the SCAA on studied Quenstedtoceras shells varies from $55^{\circ}$ to $80^{\circ}$. The ratio of the SCAA to the calculated shell diameter ranges from 2.04 to 6.12. However, in only one specimen (Fig. 7D) where the width of the supracephalic area does not exceed the width of the aperture, the ratio is less than 3 .

\section{Amoeboceras}

Amoeboceras shells are strongly ribbed oxycones with a prominent serrated keel (Figs 10, 11); these are the most strongly ribbed shells of all studied genera. The Amoeboceras specimens have a well-preserved brown wrinkle layer (see Figs 10, 11), while the imprints of this layer are not preserved in this genus. The average SCAA length in Amoeboceras is $48^{\circ}$. Although these ammonites being distant descendants of Quenstedtoceras and Pseudocadoceras, the ratio of the SCAA to the calculated shell diameter is relatively small with a value of 1.78 . The surface structure of the wrinkle layer markedly differs among the specimens and on the different parts of the SCAA (Figs 8B, 9B). Similar variations in structure and micro-ornamentation of the wrinkle layer surface were described previously (Korn 1985, Kulicki et al. 2001).

\section{Sublunuloceras}

Sublunuloceras shells are thin streamlined oxycones with a sharp keel and smooth shell surface (Fig. 12A, B). They have large well-preserved SCAAs (approximately $70^{\circ}$ in angular length), which are partially pyritized and retain a surface structure with a geometrically regular reticulate pattern: they are covered by longitudinal lines, which are 

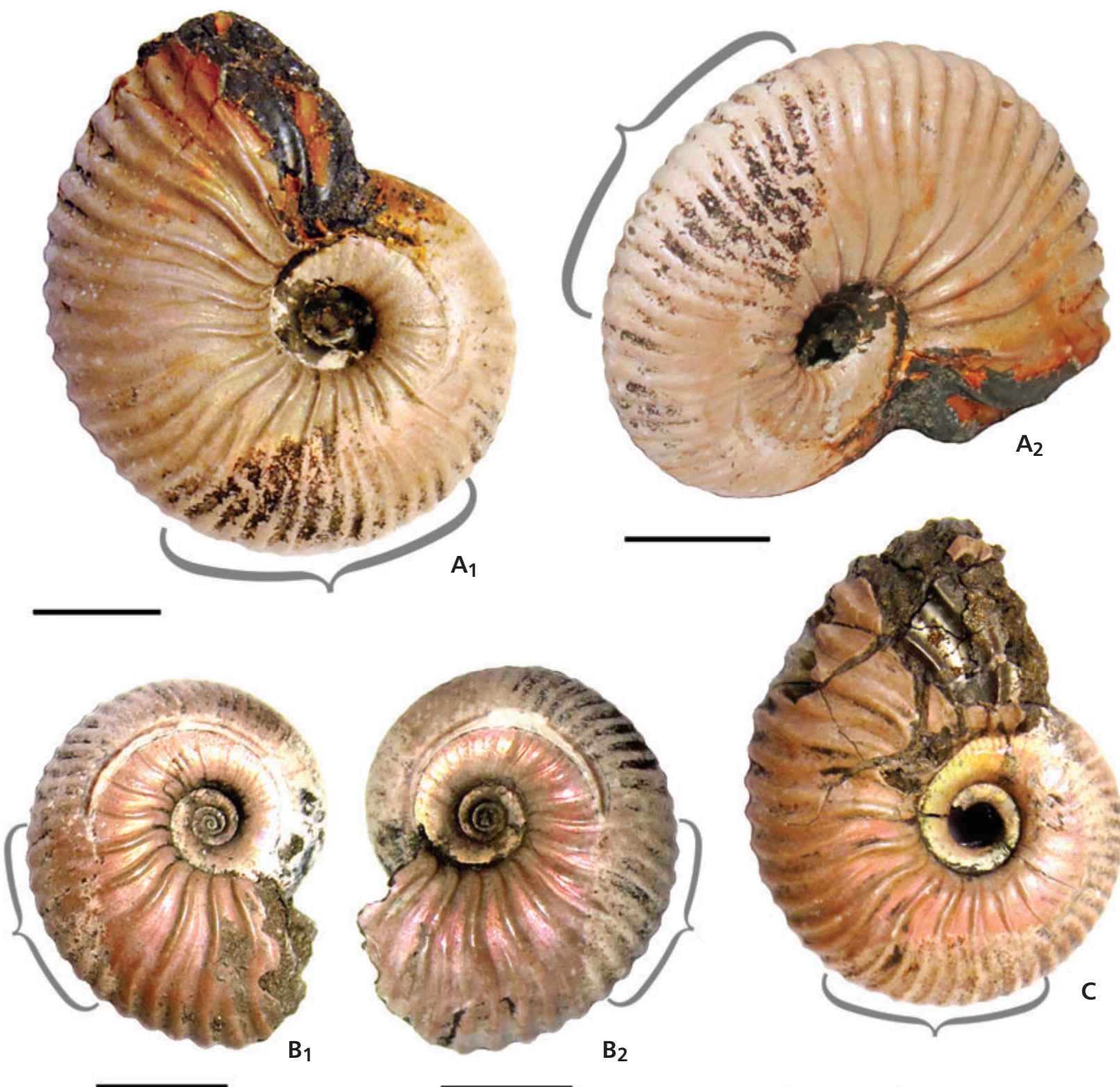

Figure 5. The SCAA and remnants of the wrinkle layer on Pseudocadoceras shells. Pseudocadoceras sp. • A - specimen MSU 115/10; B - MSU 115/22 (presumably juvenile ammonite); C - MSU 115/11. Middle-Upper Callovian, Mikhailov locality. Scale bars $1 \mathrm{~cm}$.

intersected by transverse ridges (Fig. 8C). Similar longitudinal lines were observed on the shells of Amaltheus (for example see Amaltheus subnodosus in Keupp 2000, p. 27). The genus is characterized by the largest ratio of SCAA to the calculated shell diameter among the studied ammonites, which is 6.40 .

\section{Kosmoceras}

Kosmoceras shells (Fig. 12C, D) are decorated with numerous spines and ribs and have a flat ventral side. They preserve wrinkle layers and SCAAs in front of the aperture.
However, the structure of the wrinkle layer surface is indistinguishable. The SCAA of this genus is very small: the angular length is only $22^{\circ}$, the ratio of the SCAA to the shell diameter is 0.51 .

\section{Peltoceras}

Peltoceras shells are ribbed serpenticones. Only one fragment (Fig. 13) of a Peltoceras phragmocone with preserved SCAA is available for study. An approximate estimate of the diameter of the shell was calculated by means of an analogy of the fully preserved shells from the same locality 

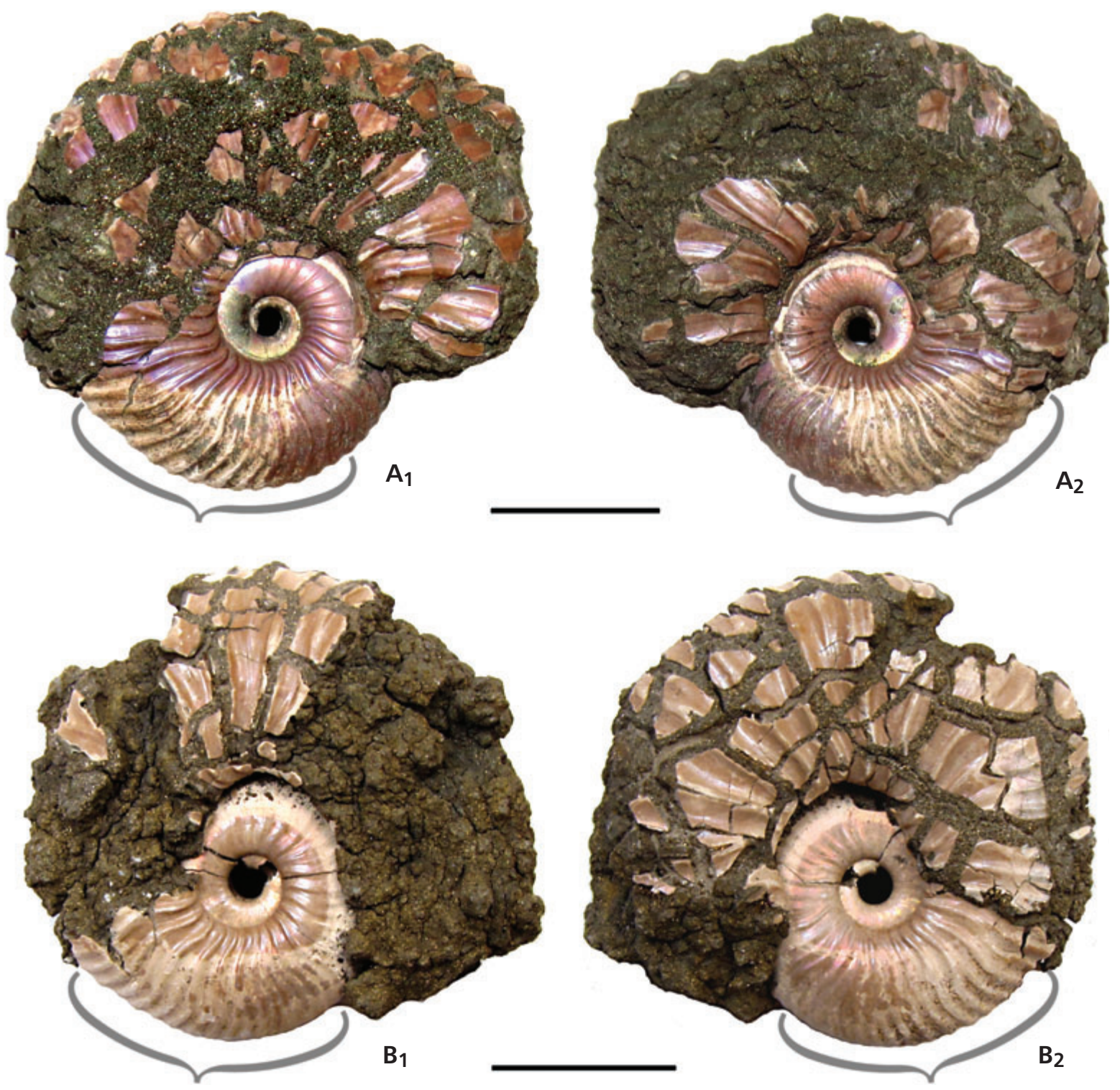

Figure 6. The SCAA on Pseudocadoceras shells. Pseudocadoceras sp. with partially preserved pyritized body chambers. • A - specimen MSU 115/18; B - specimen MSU 115/4. Middle-Upper Callovian, Mikhailov locality. Scale bars $1 \mathrm{~cm}$.

and same layers. The SCAA is well-preserved on this specimen as a brown phosphate material; its surface is covered by numerous transverse wrinkles (Fig. 9C). The angular length of the SCAA is about $22^{\circ}$. The ratio of the SCAA to the calculated shell diameter is 1.35 .

\section{Binatisphinctes}

Binatisphinctes shells are platyconic with smooth ribs and parabolic nodes on the early whorls. In the macroconch shell (Fig. 14A), the wrinkle layer, which formed the SCAA is preserved. In the microconch (Fig. 14B), this layer is dissolved, only its imprint is visible. The SCAA of the macro- conch is smooth in the center while its edges display circular and subcircular elements (Fig 8D). The microconch's SCAA exceeds the aperture width. The ratio of the SCAA to the shell diameter is 1.69 in average; the SCAA angular length is $35^{\circ}$ in the microconch and $20^{\circ}$ in the macroconch.

\section{Discussion}

Variability in the width of the supracephalic attachment areas

Kulicki (2001) noted that the area covered by the wrinkle layer outside of the body chamber may exceed the aperture 

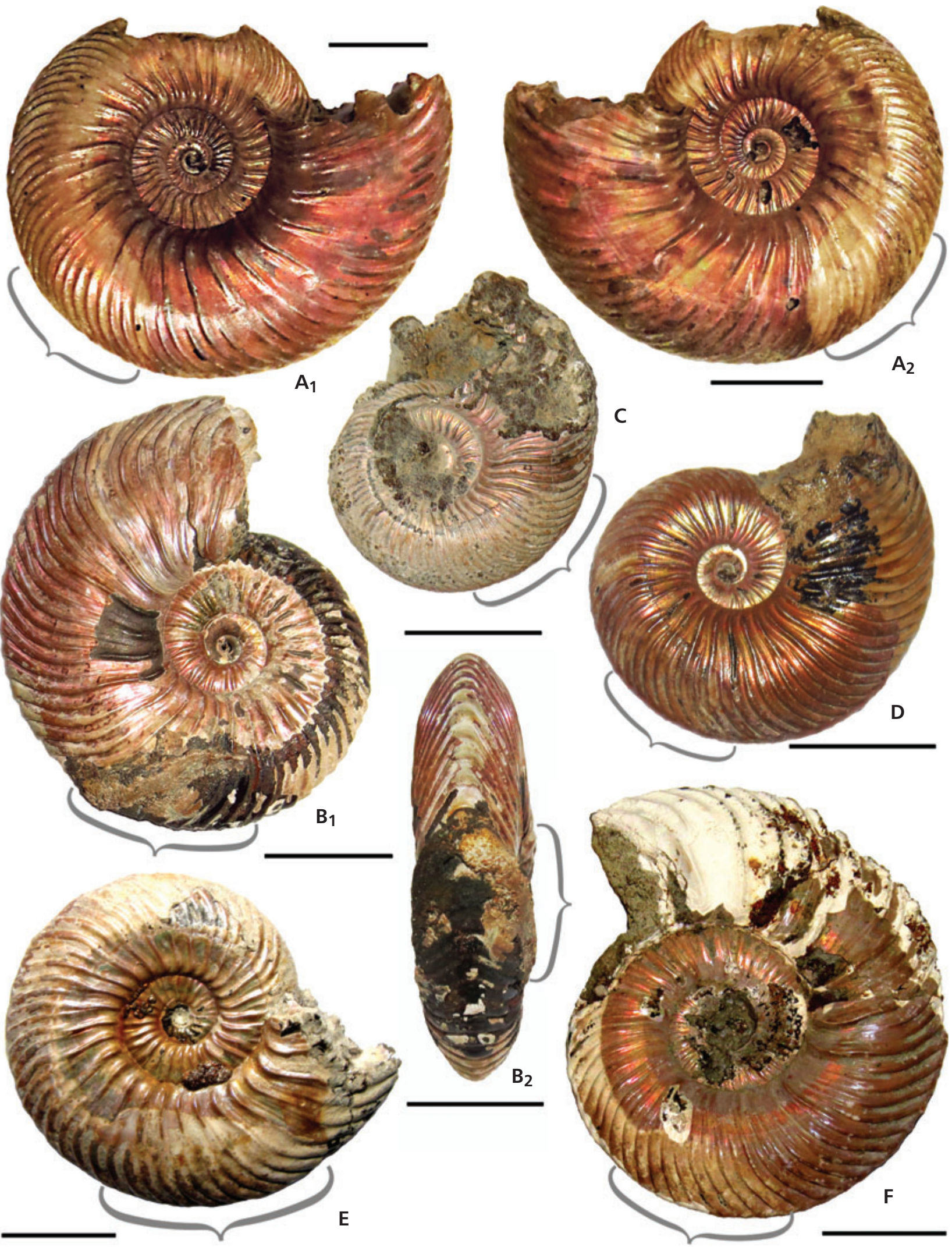

Figure 7. The SCAA on Quenstedtoceras shells. Quenstedtoceras lamberti. • A - specimen MSU 115/1; B - MSU $115 / 5$ with partially pyritized supracephalic attachment area; C - MSU 115/20; D - MSU 115/28, presumably juvenile ammonite; E - MSU 115/2 - relatively small specimen with large supracephalic area. $• \mathrm{~F}$ - Quenstedtoceras cf. flexicostatum, specimen MSU 115/7. Upper Callovian, Dubki locality. Scale bars $1 \mathrm{~cm}$. 

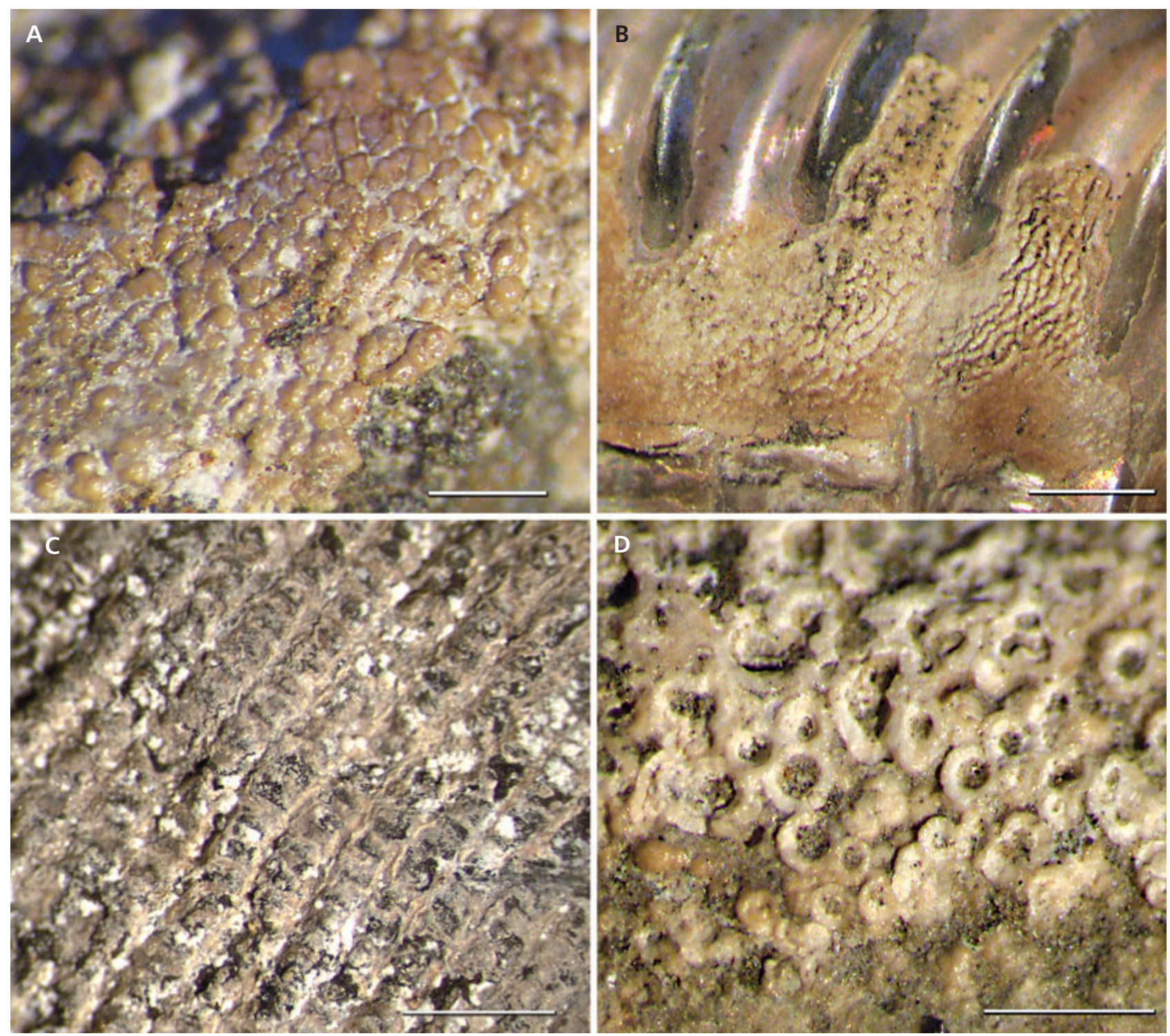

Figure 8. The structure of the dorsal wrinkle layer in the SCAA. • A - Quenstedtoceras lamberti (MSU 115/5), scale bar $0.5 \mathrm{~mm}$. $\bullet$ B - Amoeboceras alternoides (MSU 115/9), scale bar $2 \mathrm{~mm}$. $\cdot \mathrm{C}$-Sublunuloceras lonsdalii (MSU 115/3), scale bar $1 \mathrm{~mm} \cdot \bullet \mathrm{D}-$ Binatisphinctes sp. (SPC 112M), scale bar $0.5 \mathrm{~mm}$.

width or be narrower. The examination of Jurassic ammonites from the Russian platform shows that the width of the SCAA varies within a single species. For example, the SCAAs in Pseudocadoceras microconchs MSU 115/10 and MSU 115/11 (Fig. 5A, C) are wider than the aperture, while in specimen MSU 115/22 (Fig. 5B), it is narrower. In all studied Quenstedtoceras (Fig. 7) with the exception of one relatively small shell (Fig. 7D), the SCAA is wider than the aperture. Both specimens which have a narrow SCAA (Figs 5B, 7D) are smaller than their relatives. Their SCAAs are not only narrower, but shorter than in other specimens of the same genera.

The dorsal wrinkle layer was observed in ammonoids starting from the earliest shell whorls (Keupp 2000,
Kulicki et al. 2001, Korn et al. 2014). Recent Nautilida also have their black layer since the time of hatching. Therefore, the SCAAs were formed not only at the adult stage but also at immature stages. If the attachment areas at the immature stages had been wider than intermediate apertures, their borders could have protruded from the umbilical wall which would have been visible on the surface of the previous whorl. However, there are no such traces on the studied specimens. The traces of black layer can be visible at the umbilical seam of the Lower Jurassic Psiloceras (Klug et al. 2007, text-fig. 5) and Recent Allonautilus (Klug 2004, fig. 1) shells, but they are narrow, without periodic extensions. Therefore, it can be assumed that the SCAA is wider than the aperture only in mature 

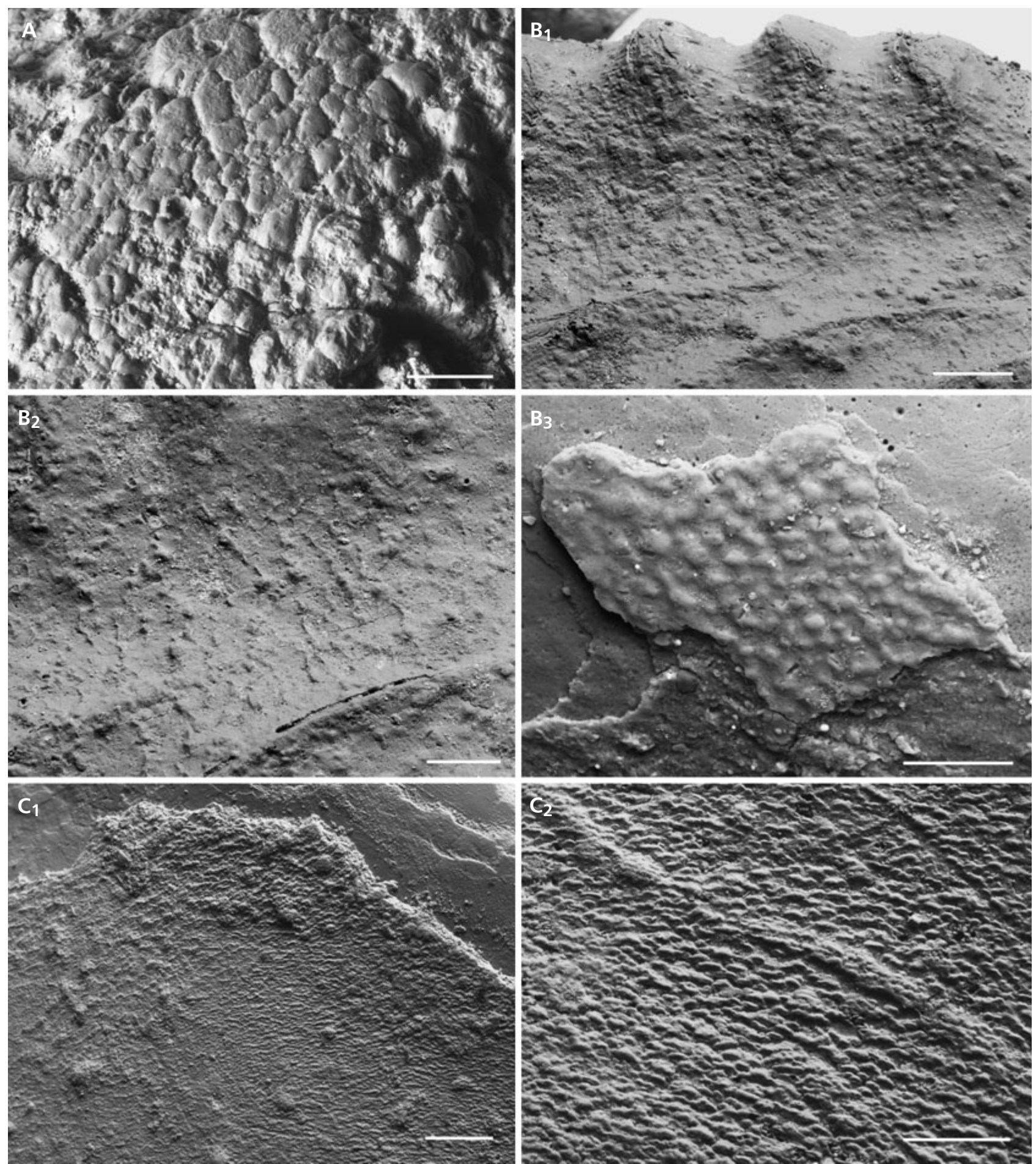

Figure 9. The structure of the dorsal wrinkle layer in the SCAA under scanning electron microscope (SEM). $・$ A - Quenstedtoceras lamberti (MSU 115/5), scale bar $300 \mu \mathrm{m}$. $\bullet \mathrm{B}-$ Amoeboceras alternoides (MSU 115/19), scale bar $\mathrm{B}_{1} 300 \mu \mathrm{m}, \mathrm{B}_{2} 200 \mu \mathrm{m}, \mathrm{B}_{3} 100 \mu \mathrm{m}$. $\bullet$ - Peltoceras arduennense (MSU 115/23), scale bar $\mathrm{C}_{1} 300 \mu \mathrm{m}, \mathrm{C}_{2} 200 \mu \mathrm{m}$.

ammonites. At the young stages of development, the width of the SCAA does not exceed the width of the aperture, and only after reaching maturity, the ammonite formed a wider
SCAA. Small specimens with narrow SCAA can thus be assumed to be shells of ammonites which had died before maturation. 


\section{Comparison of supracephalic attachment areas of the studied ammonites}

The maximum length of the SCAA was found in Pseudocadoceras. It is $92^{\circ}$ in average for all studied specimens of this genus when including the juvenile specimen (Fig. 5B) and $97.5^{\circ}$ in average for adult shells. Sublunuloceras has the second largest SCAA: angular length is $70^{\circ}$ in average followed by Quenstedtoceras with $61.7^{\circ}$ (64 for adult she1ls), Amoeboceras with $48.5^{\circ}$, Binatisphinctes with $26.7^{\circ}$, Peltoceras with $25^{\circ}$ (measured only one specimen) and Kosmoceras with $22^{\circ}$ in average (Table 1 ). Although it is logical to assume that the shell shape only determines the width of the SCAA (since the wrinkle layer covers the surface of the previous whorl and its area is related to the whorl overlap), the measurements indicate that the length of the SCAA is also related to shell shape. Ammonites which have the longest SCAA have oxyconic (Sublunuloceras) and relatively smooth streamlined discoconic shells (Pseudocadoceras, Quenstedtoceras). Ammonites with relatively wide, ribbed and spiny shells have significantly shorter attachment areas.

The ratio of the SCAA to the calculated shell diameter was also measured (Fig. 15). Here, the sequence of taxa turned out similar, but it differs in the details. The largest ratio was calculated for Sublunuloceras shells (6.40 in average) and the second largest was found in Pseudocadoceras (average ratio of adult shells is 4.98). The third largest was calculated for Quenstedtoceras and is 3.91 in average for all shells and 4.28 among adults. However, this latter genus displays great differences between specimens in this parameter: the ratio of SCAA to phragmocone diameter varies from 3.22 to 6.12 (the last value is close to the values of Sublunuloceras) in adult shells and 2.04 in presumably immature specimen. As the adult shells differ in ornament strength, whorl thickness, and the degree of coiling, it can be assumed that this difference is due to intraspecific variability. The fourth largest value was found in Amoeboceras, where the ratio amounts to 1.78 , followed by Binatisphinctes (1.69), Peltoceras (1.35) and finally Kosmoceras (0.51). The relatively small ratio of SCAA to shell diameter detected in Amoeboceras shells may seem strange, because these ammonites are close relatives to Pseudocadoceras and Quenstedtoceras, but Amoeboceras also has a strong ornament. The SCAA covering the ribs in Amoeboceras exceeds the simple length/width measurement which was applied here due to the extreme shell profile.

As mentioned above, the comparison of the ratio be- tween SCAA and body-chamber lengths (Klug et al. 2004) is impossible in the majority of the ammonites used for this study because of the difficulty of determining the position of the last septum and the body chamber length. In some cases, however, the approximate body chamber length could be determined. The comparison of body chamber length between different ammonite genera did not produce any confirmation of the relationship between the size of the SCAA and the length of the body chamber. For example, in Binatisphinctes (Fig. 14A) and Sublunuloceras (Fig. 12A, B), the length of the body chamber does not greatly differ (about $200^{\circ}$ in microconch of Binatisphinctes and $190^{\circ}$ in macroconchs of Sublunuloceras), but the dimensions of the SCAA are completely different (Table 2). Nevertheless, within one genus, the body chamber length and the dimensions of the SCAA correlate positively. For example, in the Quenstedtoceras microconch MSU 115/1 (Fig. 7A), the body chamber is shorter than in MSU 115/2 (Fig. 7E), which belongs to the same genus. The relative size of the SCAA in MSU 115/2 is greater than in the MSU 115/1. Perhaps this indicates that within one species, the length of the SCAA is proportional to the length of the body chamber. However, only few specimens are suitable for measuring the body chamber length and it is impossible to correctly test this assumption until more material becomes available.

At the same time, measurements show that there is no correlation between the length of the SCAA and the height of the aperture (Klug et al. 2004) in my material. Both Sublunuloceras and Kosmoceras have rapidly increasing whorl heights and high apertures (Fig. 12). However, the ratio of the length of the SCAA to the aperture height is completely different between these two genera (Table 2).

Therefore, I detected only one relationship: the SCAA's shape and size correlates apparently with the overall ammonite shell shape. Streamlined oxyconic Sublunuloceras, keeled Quenstedtoceras and discoconic Pseudocadoceras have larger attachment areas than ammonites with platyconic or serpenticonic shells (Kosmoceras, Peltoceras and Binatisphinctes) which have relatively small areas.

\section{Did ammonoids have a hood?}

Several researchers raised the question about the Nautilus-style hood in ammonoids. One of the functional interpretations of the black or wrinkled supracephalic attachment area in ammonoids is that it was not only a place

Figure 10. The SCAA with a preserved wrinkle layer on Amoeboceras alternoides shells. Amoeboceras alternoides. $\bullet$ A - specimen MSU 115/14; B - MSU 115/16; C-MSU 115/8; D - MSU 115/17; E- MSU 115/19; F- MSU 115/6; G - MSU 115/15; H - MSU 115/24. Upper Oxfordian, Markovo locality. Scale bars $1 \mathrm{~cm}$. 

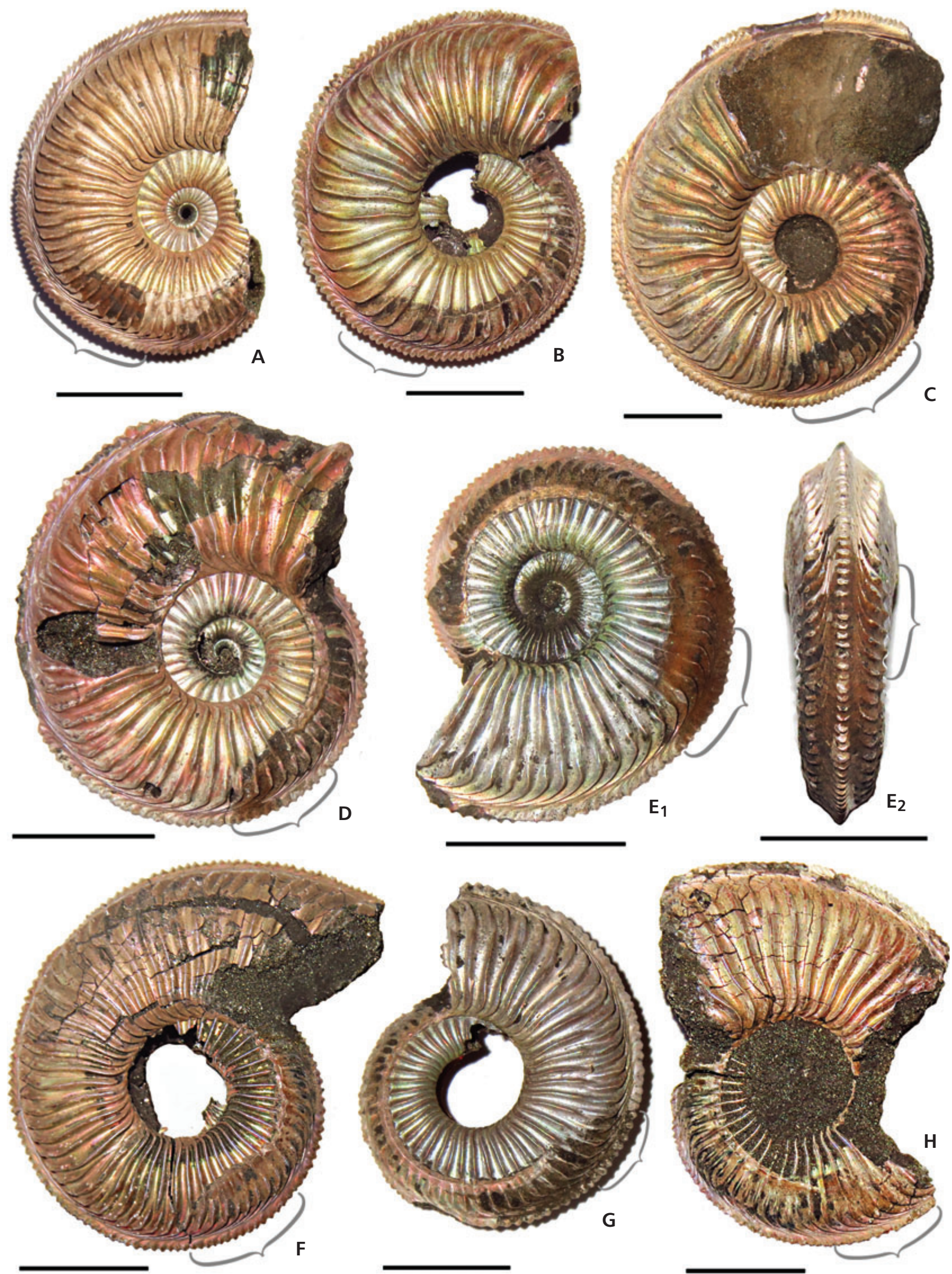


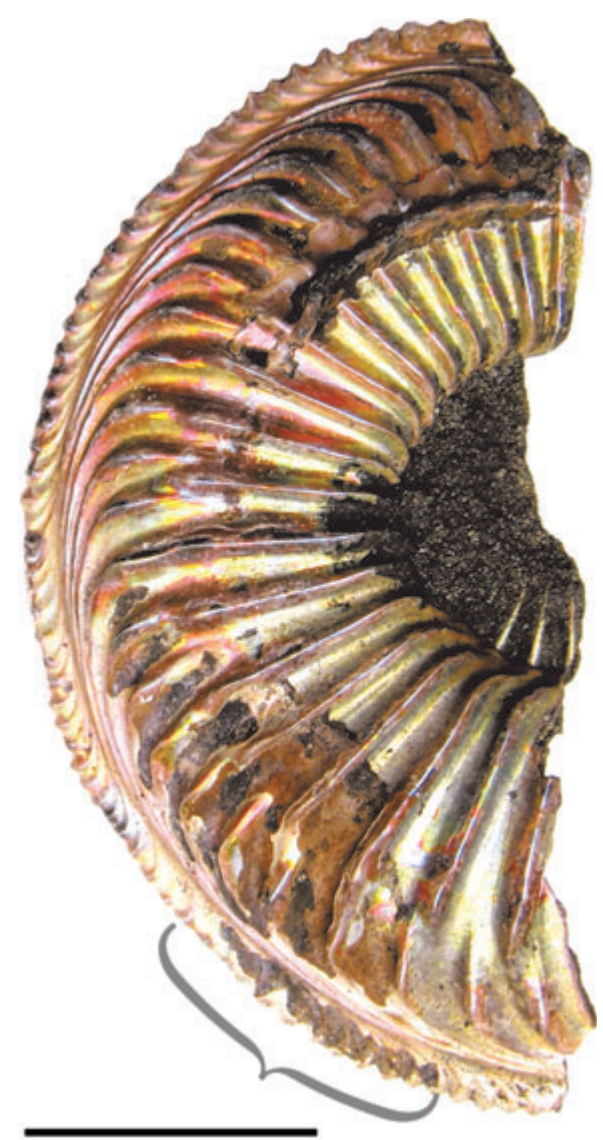

for a supracephalic mantle fold, but possibly also for a hood attachment (Klug et al. 2004, Korn \& Klug 2012). However, the presence of a large protective hood in the ammonite soft body appears unlikely for several reasons.

Most Mesozoic ammonites had aptychi which might have served as a lower jaw and an operculum simultaneously (Lehmann \& Kulicki 1990, Parent et al. 2014); however, there is an ongoing debate on the double function of aptychi. In the case of finds of the SCAA on the shells of Paleozoic or Triassic aptychi-less ammonoids (Klug et al. 2004), one might assume that these ammonites could not have used the lower mandibles for protection of the aperture and they needed a hood for this purpose. Klug et al. (2004) noted, that co-existence of a hood, as in modern Nautilus and aptychi, functioning as opercula in one ammonite, appears unlikely. In my material, the SCAA was found on the shells of aptychi-bearing ammonites. Aptychi are known from all of the ammonites studied here (Table 3). Moreover, the SCAA had been previously described in ammonites with aptychus-type jaws: Quenstedtoceras sp. (Kulicki 1979, Kulicki et al. 2001) and Aconeceras trautscholdi (Kulicki et al. 2001).

The co-existence of the SCAA and aptychi cannot be regarded as a sufficient argument against aptychi protective function, as suggested by Klug et al. (2004). Existence of the SCAA (or black layer) does not proof a Nauti-
Figure 11. The SCAA with preserved wrinkle layer on Amoeboceras alternoides shells. Amoeboceras alternoides. • A - specimen MSU 115/13; B - MSU 115/12. Upper Oxfordian, Markovo localitiy. Scale bars $1 \mathrm{~cm}$. lus-style hood (Keupp 2000, Lehmann et al. 2014). Griffin (1900) suggested that the black layer in front of apertures of Nautilus shells can be formed by the apical part of the hood. Now it is known that in Nautilida, the mantle margin secretes the black layer and the black band on the aperture (Senior 1971, Kulicki et al. 2001, Klug et al. 2007). More precisely, the black layer in Nautilus shells is secreted by the supracephalic mantle fold (Senior 1971, Kulicki et al. 2001). Therefore, the dark-colored SCAA is not necessarily associated with the Nautilus-style hood, but it is an indicator for the presence of the supracephalic mantle fold in the ammonoid soft body.

The hood of Recent Nautilus and Allonautilus is an interesting and complex organ. During the embryonic development, the hood forms from two dorsal arm pairs together with ocular tissue and part of the collar/funnel complex (Shigeno et al. 2008). Recent Nautilus embryos are quite similar to coleoid embryos in having five pairs of primordial arms. During embryogenesis, two basic Nautilus arm pairs change into part of the hood leaving three arm pairs to become divided into a large number of tentacles (Shigeno et al. 2008). If it were not for the splitting of primordial arms into a set of tentacles, the Nautilus would have only six arms. Likely, development of the hood became possible after the number of tentacles in the evolution of the Nautilida increased, especially because during the embryonic 

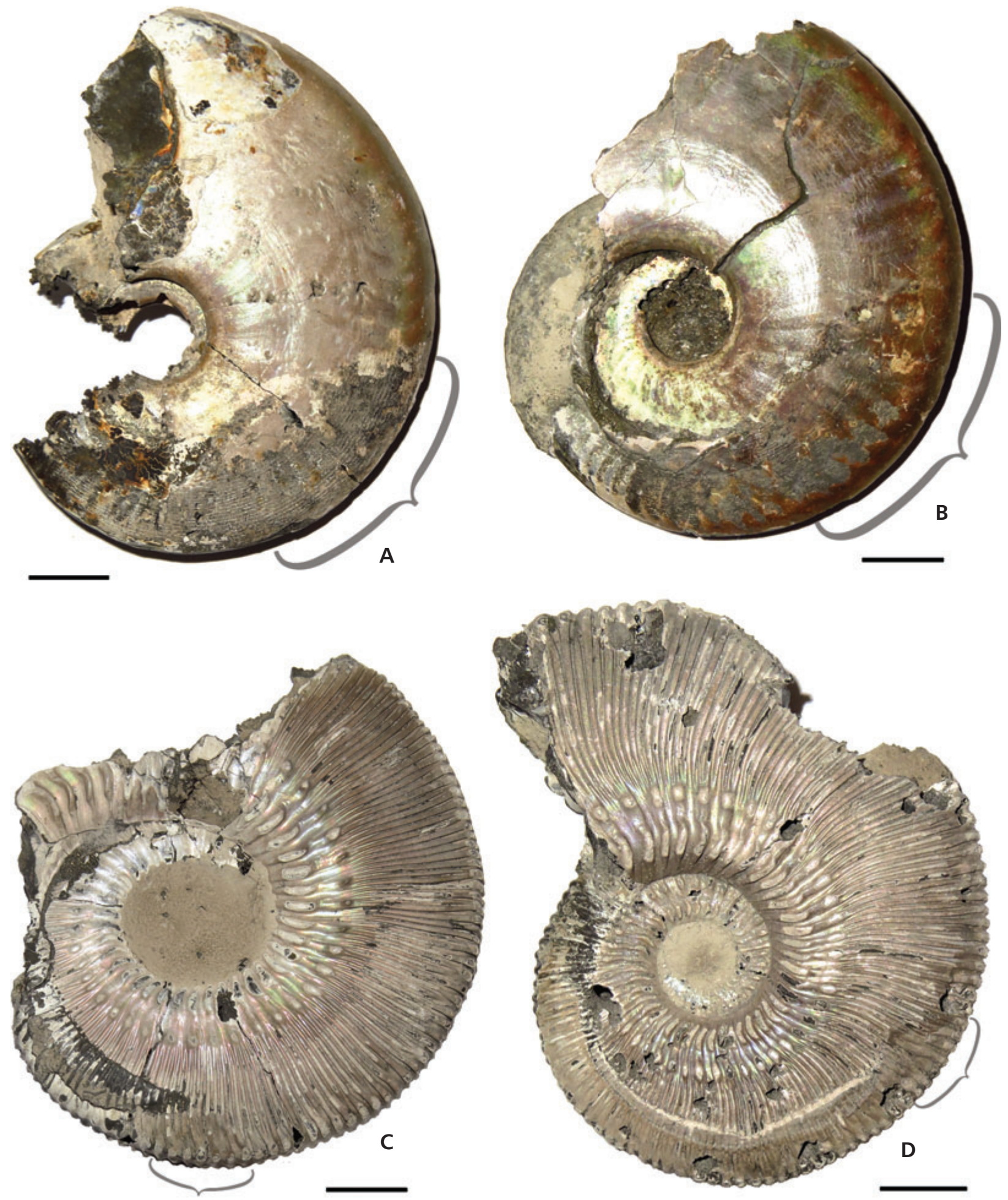

Figure 12. The SCAA with preserved wrinkle layer on Sublunuloceras lonsdalii and Kosmoceras proniae shells. • A, B - Sublunuloceras lonsdalii; A - MSU 115/3; B - MSU 115/21. Both specimens are macroconchs. Upper Callovian, Mikhailov locality. Scale bars $1 \mathrm{~cm}$ • C, D - Kosmoceras proniae; C - MSU 115/26; D - MSU 115/27; Both specimens are large microconchs. Upper Callovian, Mikhailov locality. Scale bars $1 \mathrm{~cm}$.

development of Nautilus, the hood forms later than the subdivision of the primordial arms (Shigeno et al. 2008). To date, the arms of ammonoids are unknown from the fossil record. However, ten arms (five pairs) represent the plesiomorphic state in the Cephalopoda (Klug \& Korn 2004, Shigeno et al. 2008). It is known that Ammonoidea 

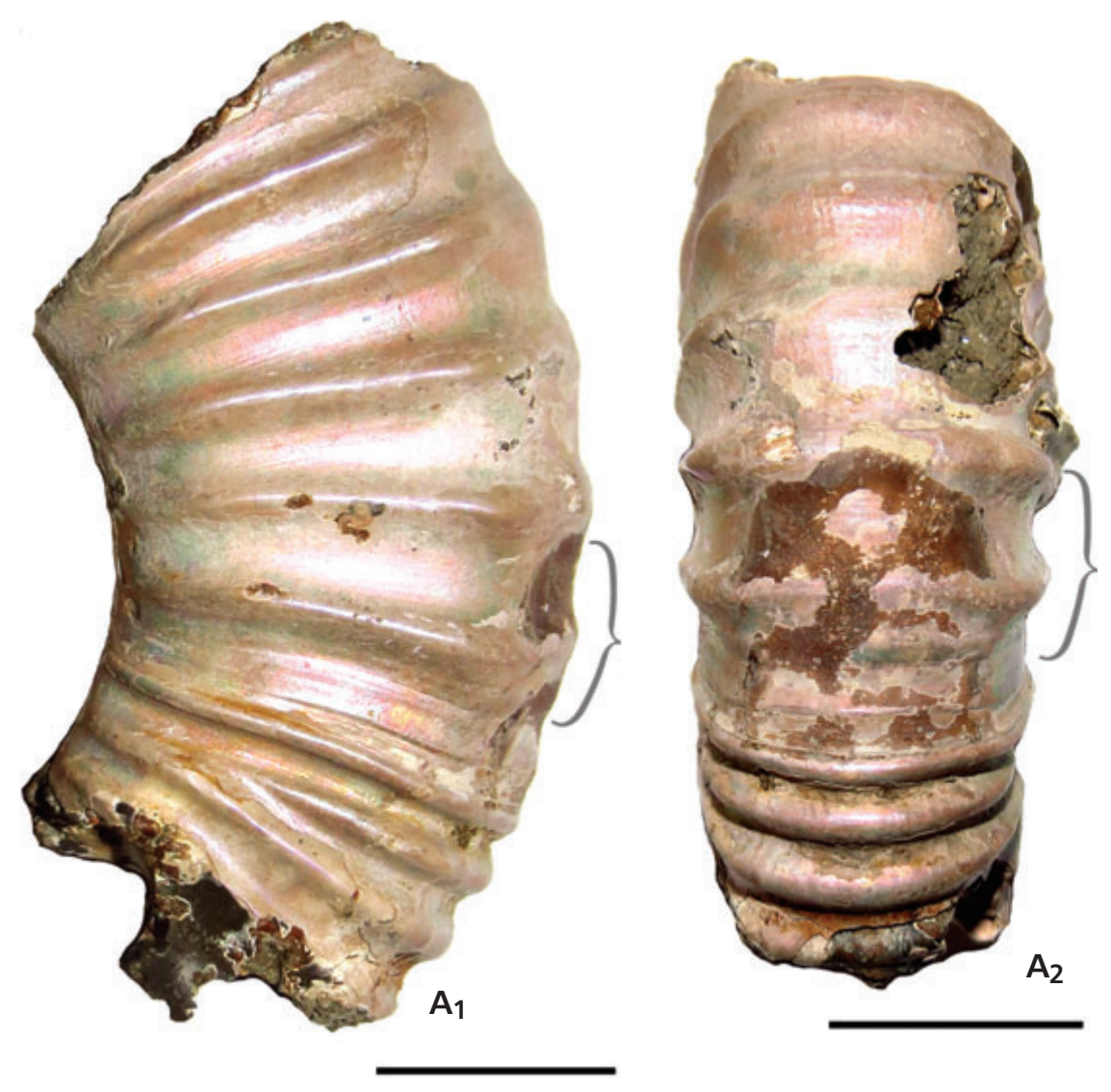

Figure 13. The SCAA with a preserved wrinkle layer on Peltoceras arduennense shell. Peltoceras arduennense, specimen MSU 115/23: $A_{1}$ - lareral view; $A_{2}$ - ventral view. Upper Callovian, Dubki locality. Scale bars $1 \mathrm{~cm}$. and the Coleoidea are descendants of the Bactritida (Kröger et al. 2011). Coleoids have ten arms and they branched off from their ancestors later than ammonoids did. Previously, when it was believed that the hood is a completely separate organ, it could be assumed that the hood disappeared in Coleoidea when their shell became internal. However, now we know that the hood is formed partly from the arms; therefore, if coleoid ancestors had a hood, they should have only two or three pairs of free arms. Also, a formation of the hood was not observed in coleoid embryonic development (Shigeno et al. 2008). Thus, the ancestors of coleoids likely had no hood and ammonites inherited ten arms from their ancestors but did not inherit a nautilid-like hood. It is unlikely that ammonoids would have independently and completely repeated the evolutionary path of the Nautilida and developed such a complex organ with regard to their differences from nautilids (Jacobs \& Landman 1993).

In addition, Keupp (2000) concluded that the size and shape of the SCAA ("Runzelschicht") in the ammonite shells differs from the shape and position of black layer in Recent Nautilus shells. Based on the above arguments, it can be concluded that ammonites had no hood comparable to that of modern nautilids.

Since the Nautilus black layer is formed by the supracephalic mantle fold, the researchers concluded that ammonites had a supracephalic mantle fold which formed the SCAA and was attached to it (Kulicki et al. 2001, Klug et al. 2004). However, the main function of the supracephalic mantle fold in nautilids is the formation of a black layer which is used for mantle and hood adhesion. But if ammonoids did not have a hood, why would the dorsal mantle have formed a SCAA, especially taking into account its large size in many ammonites? Moreover, the SCAA in some ammonites (Sublunuloceras, Amaltheus) has a complex and very rough surface which can be interpreted as an adaptation to strengthen the adhesion of the soft tissues. If this assumption is true, this area would have been subjected to some mechanical stress. However, it is difficult to imagine the cause of such forces acting on the supracephalic mantle fold. Therefore, along with the supracephalic mantle fold another soft-tissue structure could have been attached to the SCAA in ammonoids.

A dorsal part of the Nautilus hood forms during embryogenesis from the enlarged anterior part of the collar (Shigeno et al. 2008). Specifically, this dorsal part of the hood is attached to the edges of the black layer along with the mantle fold. The portion of the collar, which is included in the hood, is possibly responsible for the attachment of the Nautilus hood to the black layer. I suggest that ammonoids did not have a large nautilid-like hood, but a "protohood": a free (unmerged with arms/tentacles) dorsal 

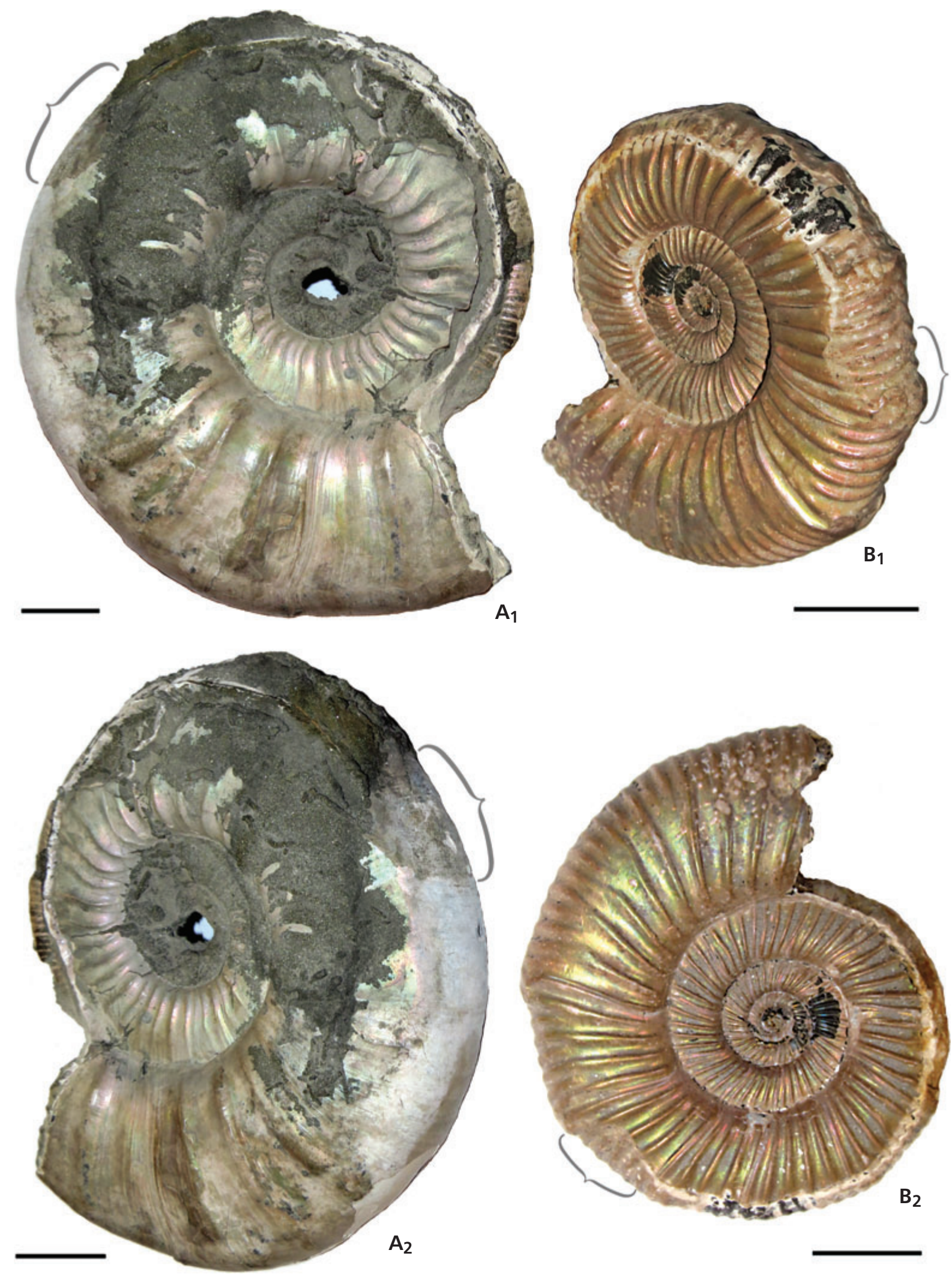

Figure 14. The SCAA on Binatispinctes shells. • A - Binatisphinctes sp. macroconch shell with preserved wrinkle layer, specimen SPC 112M. Scale bar $2 \mathrm{~cm}$. $\bullet$ B - Binatisphinctes sp. microconch shell, specimen SPC 15M. Middle-Upper Callovian, Mikhailov locality. Scale bar $1 \mathrm{~cm}$. 
Table 3. Aptychi which belong to ammonites from studied families.

\begin{tabular}{lll}
\hline Ammonite family & Aptychus type & Source of information \\
\hline Kosmoceratidae & Granulaptychus, Kosmogranulaptychus & Schweigert (2000), Rogov (2004), Mitta \& Keupp (2004), Keupp \& Mitta (2013) \\
Cardioceratidae & Praestriaptychus & Lehmann (1972), Engeser \& Keupp (2002), Mitta \& Keupp (2004) \\
Perisphinctidae & Praestriaptychus & Engeser \& Keupp (2002), Rogov \& Gulyaev (2003), Rogov (2004) \\
Aspidoceratidae & Laevaptychus & Engeser \& Keupp (2002), Rogov (2004) \\
Oppeliidae & Lamellaptychus & Engeser \& Keupp (2002) \\
\hline
\end{tabular}

part of the collar fold located above the head. Although there is no such dorsal collar projection in modern Cephalopoda, Shigeno et al. (2008) showed that the Nautilus hood is a secondarily-derived structure and the cephalopod embryo has an anterior part of the collar, which could have become a "protohood" in ancient cephalopods (this embryonic tissue is marked as "hood" in Shigeno et al. 2008, figs 3, 4 and as "dorsal hood" in Shigeno et al. 2008, fig. 7). Lehmann et al. (2014) recently discussed the possibility of the existence of a hood-like structure in ammonoids, not necessarily similar in shape and function to Nautilus hood. It is possible that the dorsal collar fold was attached to the edges of the supracephalic attachment area along with the mantle fold in the same way as the $\mathrm{Nau}$ tilus hood which is partially formed from this part of the collar. The dorsal collar extension ("protohood" or "hoodlike structure" sensu Lehmann et al. 2014) could have differed from the hood of living nautilids by the fact that it was not fused with tentacles during embryogenesis. Therefore, this "protohood" might have been relatively small and might have been unable to close the aperture entirely (which would explain the possible use of aptychi for the protection of the body chamber in some ammonoids). Since the distal margins of the collar and hyponome are fused in cephalopods (Bizikov 2002, 2008), this fusion with the "protohood" may have served as a bond between the hyponome, collar folds and the attachment area on the previous shell whorl in ammonoids. Ultimate proof for any of these hypotheses can come only from preserved soft tissues which have not been found yet.

\section{Did ammonoids have an internal shell?}

Some researchers discussed the possibility that some ammonites might have been endocochleate, i.e. their shells were more or less covered by the mantle (Doguzhaeva \& Mutvei 1991, 1993a, b; Korn 2000; Doguzhaeva 2012). These assumptions contradict several peculiarities of ammonoid paleoecology and paleobiology. For example, many ammonite shells are decorated with sharp spines and other protruding sculptural elements and it is difficult to envision that these elements were covered by the mantle. The color pattern of ammonoid shells is also reasonably well known (Mapes \& Davis 1996). Ammonite shells often bear epifauna overgrown by shell whorls formed later
(Keupp 2000, Larson 2007, Andrew et al. 2011), which demonstrates syn vivo attachment of these organisms to the ammonite shell. It appears unlikely that epizoans were capable to settle on a living ammonite if the shell was covered by the soft-tissues.

An additional organic-rich layer found between the whorls of perisphinctid ammonites and interpreted as an outer coating layer used for soft-tissue attachment (Doguzhaeva 2012) is certainly a wrinkle layer, judging by its position on the shell and its high organic content. The fact that its edges can be seen along the umbilical seam does not indicate that it could have covered the entire shell surface since the edges of the black layer of Recent Allonautilus and Lower Jurassic Psiloceras are also visible along the umbilical seam (Klug 2004, fig. 1; Klug et al. 2007, text-fig. 5). The interpretation of parabolae as areas of the external mantle attachment is also doubtful due to their irregular location on many shells (Keupp 1973). Sometimes, there are 1-2 parabolae per whorl on perisphinctid ammonites (Glowniak \& Wierzbowski 2007), whereas such an irregularity of the soft tissue attachment areas has never been described.

The presence of the SCAA on the surface of the ammonoid shell, homologous to that of the living Nautilus and Allonautilus, is additional evidence against the "endocochleate hypothesis". The fact that the mantle needs a special adhesive area (SCAA) for its attachment indicates that the soft tissues covered only the SCAA and not the entire outer surface of the shell. In other words, the SCAA shows that planispiral ammonites, as well as living Nautilida, had an external shell.

Only in a few ammonoids (e.g. Gaudryceras), researchers found a wrinkle layer, which covers not only parts of the previous whorl, but also the wide umbilical area (Drushchits et al. 1978, Kulicki et al. 2001) or probably parts of the body chamber (Korn 2000). In such ammonoids, the mantle could have exceeded the width of the aperture and reached the umbilical opening or extended over parts of the body chamber. Probably, the mantle also covered the apertural region of the ammonoid shell as evidenced by the black band at the aperture (Korn 2000, Klug 2004, Klug et al. 2007). There are no doubts that in the majority of ammonoids, the shell surface was not covered by the mantle with the exception of the special soft-tissue-attachment areas such as the SCAA and perhaps a thin black band behind the aperture. 


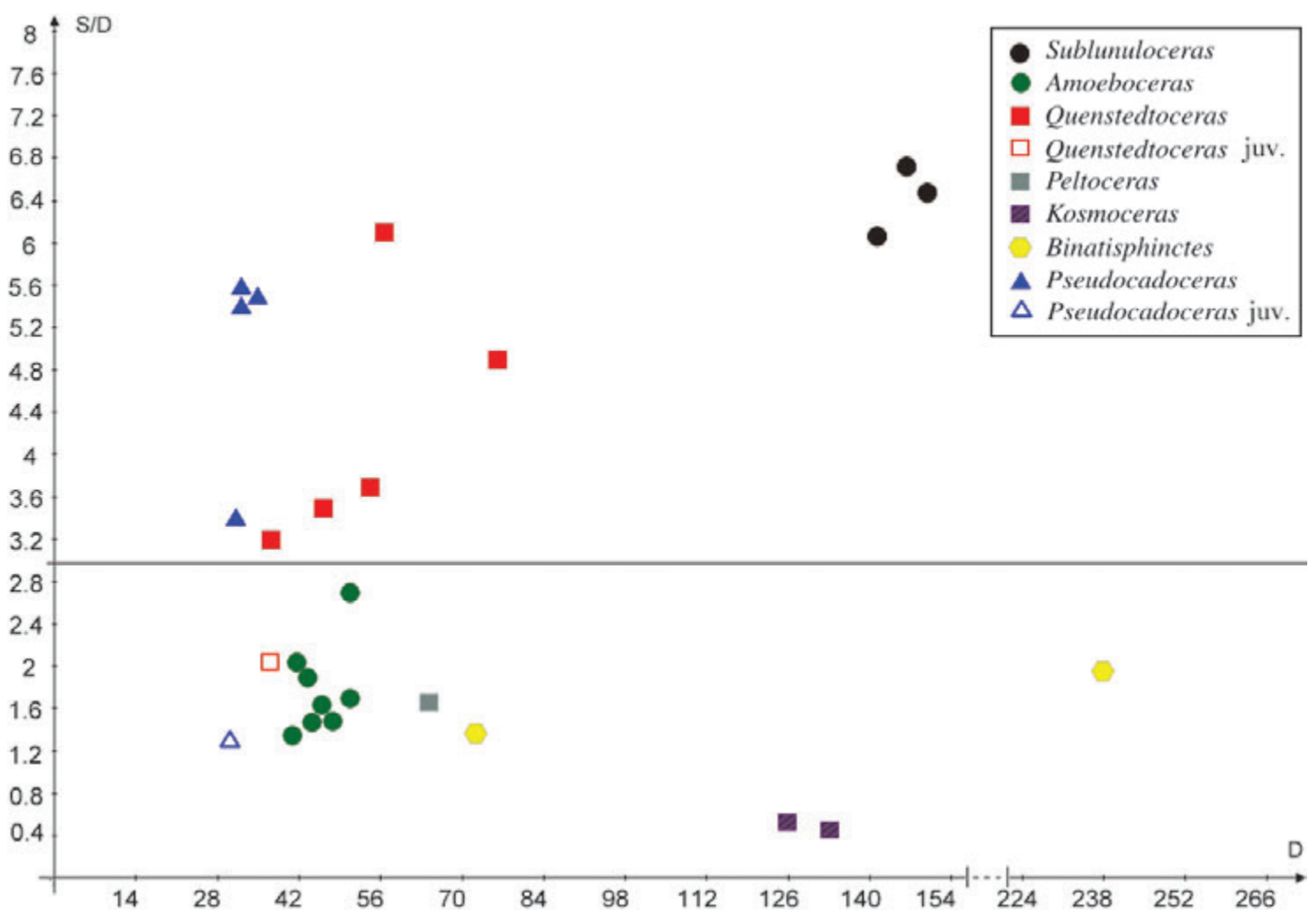

Figure 15. The ratio of the SCAA to shell diameter in relation with calculated shell diameter. S/D - the ratio of the supracephalic attachment area to shell diameter, D - shell diameter. Transparent symbols indicate presumably juvenile specimens.

\section{Supracephalic attachment area: implications for ammonoid aperture orientation}

The presence of the SCAA in ammonoid shells suggests a reconsideration of the calculations of the syn vivo orientation of the ammonoid shell aperture. Until now, size and structure of the head and arms of ammonoids are poorly known (Klug et al. 2012). However, the large size of the buccal mass likely indicates a large head. All living cephalopods including Nautilida as well as Coleoidea have their head in front of the collar (see Naef 1922, Bizikov 2008). Accordingly, the anatomy of ammonites corresponded to the anatomy of other cephalopods in their basic features. If ammonoid collar folds and a "protohood" (if it existed) had been attached to the SCAA when the animal was active, the head must have been in front of the collar, under the supracephalic mantle fold and the SCAA. Therefore, the presence of the SCAA indicates that, when the animal was active, a certain part of the ammonoid soft body was located outside of the body chamber (see also Parent et al. 2014). In many taxa, this could have been a rather heavy part of the body including the head, jaw apparatus (with large calcified aptychi in the case of ammonites with aptychus-type jaws), hyponome and arms (although it is unknown what they looked like and whether they were muscular). At the same time, in most of all computations published to date, it is explicitly or implicitly assumed that the soft body of ammonoids with planispiral shells was located entirely within the body chamber (Trueman 1941, Raup \& Chamberlain 1967, Saunders \& Shapiro 1986, Westermann 1996, Klug \& Korn 2004, Naglik et al. 2014, Tajika et al. 2015). Since these authors did not take the protrusion of the cephalic region out of the body chamber into account, the apertures of many ammonites are located in a nearly horizontal position (Trueman 1941, figs 14, 15; Saunders \& Shapiro 1986, fig. 8; Westermann \& Tsujita 1999, fig. 21.10). The results of these calculations do not explain some of the morphological shell features such as the occurrence of ventral rostra (long ventral aperture projections). Ventral rostra appeared repeatedly in different evolutionary lineages of ammonites, especially in such with more or less streamlined oxyconic and discoconic shells, possibly adapted to fast swimming (Westermann 1996). Horizontal orientation of the aperture seems problematic for understanding the mode of life of such ammonoids (e.g. Sublunuloceras, Pseudocadoceras, Quenstedtoceras and Amoeboceras studied here). The combination of the horizontal aperture with a ventral rostrum would have forced the hyponome to be directed upwards, and such a position precluded jet-propulsion swimming (Andrew et al. 2011), but this contradicts the observed streamlined shell shape of rostrum-bearing 


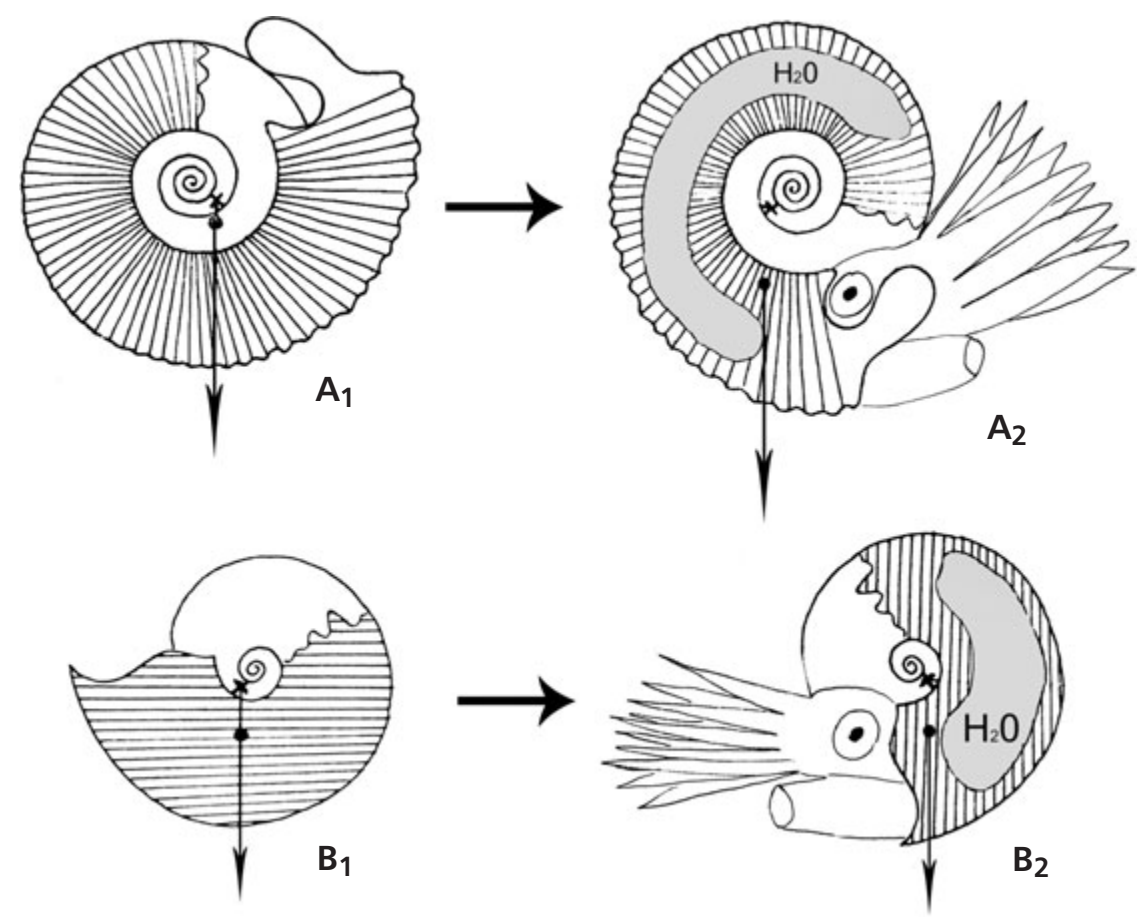

Figure 16. Scheme of changing of shell orientation due to movement of the soft body beyond the aperture and the presence of water inside mantle cavity. $\bullet$ A - mesodomic shell with lappets; B - brevidomic shell. Modified from Trueman (1941, fig. 14). The cephalic region of the ammonite soft body and location of the mantle cavity are depicted schematically.

ammonites. To solve this problem, some authors have suggested that ammonites could have had a split hyponome with one opening on each side of the rostrum (Schmidt 1930, Trueman 1941, Westermann 2013). Other authors even speculated about the possible presence of fins in ammonoids (Jacobs \& Chamberlain 1996, Andrew et al. 2011). However, double or twin-nozzled hyponomes have never been found in any modern or extinct cephalopods. Regarding the possible presence of fins in ectocochleate ammonoids, it appears highly unlikely a fortiori because fins need an internal shell for their support (Bizikov 2008). Thus, the horizontal orientation of the aperture, in combination with the streamlined shell shape and ventral rostrum (which in this case must have been directed upwards) is difficult to understand.

In fact, not all researchers were confident of the correctness of the usage of existing calculations with upward oriented apertures for reconstructions of the ammonoid mode of life and its swimming position, although the majority agrees on that. For example, Jacobs \& Landman (1993) stated that the assumption of the entire body of the ammonoid being contained within the body chamber permanently was unwarranted. They assumed that many ammonoids were capable of mantle extension and could have controlled the orientation of the shell to some degree. Doguzhaeva \& Mutvei (1991) also supposed that the cephalic region in the majority of ammonites could have been considerably extended actively out of the aperture. Parent et al. (2014) argued that the cephalic complex was mobile (could have moved outwards of the body chamber) and was denser than the intestinal complex located inside the body chamber. Zaton (2010) noted that the deduced aperture orientations are hypothetical because the distribution and weight of soft-tissues in the body chamber or the volume of cameral liquids, influenced the aperture orientation. Trueman (1941), the pioneer of the aperture orientation calculations, admitted that his mathematical estimates reflect the position of the ammonite shell in water, when the soft body was withdrawn into the body chamber: "It is probable that in many ammonites a movement of the animal's body forward beyond the aperture would bring the centre of gravity farther forward and cause a tilting of the shell: the presence of a heavy aptychus probably increased this effect" (Trueman 1941, p. 371). However, Trueman (1941) began to speculate about the ammonite habitat on the basis of calculations, in which the location of the part of the soft body outside of the body chamber was not taken into account. In subsequent publications, many researchers left out Trueman's specifications about the possibility of ammonites moving partially out of the aperture. Afterwards, Saunders \& Shapiro (1986) postulated that the "center of mass is defined as the center of gravity of the body chamber; this assumes that the total mass of the animal is dominated by the soft tissue enclosed within the body chamber" (Saunders \& Shapiro 1986, p. 65). However, the presence of the SCAA in front of the apertural 


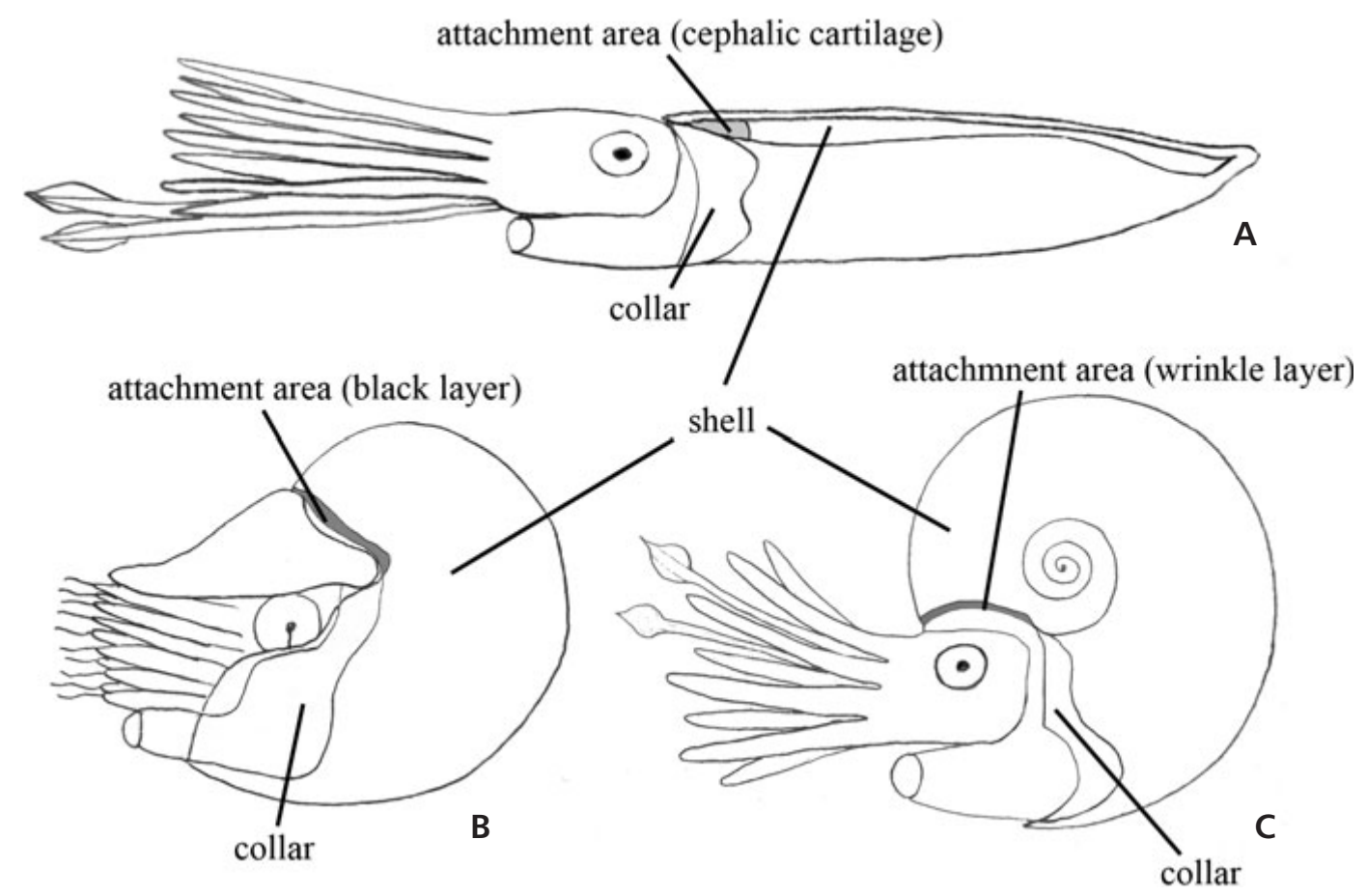

Figure 17. The scheme shows the general principle of collar attachment to the shell in cephalopod mollusks. $\bullet A-$ Coleoidea (squid). The collar folds are attached to the nuchal cartilage which is connected to the internal shell. $\bullet$ B - Nautilida (Nautilus). The collar folds are fused to the rear part of the hood and attached to the black layer. $\bullet \mathrm{C}-$ Ammonoidea (oxyconic Sublunuloceras). The collar folds and "protohood" are attached to the wrinkle layer.

edge (which was an area of soft-tissue attachment during active state) demonstrates the inaccuracy of this postulate. I am convinced that it is difficult to draw valid conclusions about aperture orientation, behavior and lifestyle of planispiral ammonoids without taking into consideration the location of the anterior part of their soft body protruding from the body chamber.

The presence of the supracephalic attachment area provides another opportunity to clarify the existing calculations of the aperture orientation. In most of the currently available models, it is assumed that the ammonoid body chamber was completely filled with soft tissues (Trueman 1941, Raup \& Chamberlain 1967, Saunders \& Shapiro 1986, Klug \& Korn 2004). If the part of the soft body had been located outside of the body chamber under the large supracephalic area, it must have been able to retract into the shell in a dangerous situation. Undoubtedly, the attachment of the mantle to the SCAA was not permanent and in ammonoids not only the cephalic region, but also the dorsal mantle fold must have been able to retract into the soft body chamber as well as in Recent Nautilida (Ward \& Saunders 1997, fig. 1-1). Consequently, there was space for retracting the cephalic region and the mantle inside the body chamber. Monks \& Young (1998) proposed that the body of heteromorph ammonites was a relatively small, compact mass partially filling the body chamber. Kröger (2002) provided supporting evidence for the correctness of the incomplete filling of the body chamber with soft tis- sues. He demonstrated that normally-coiled ammonites, especially such with longidomic and mesodomic shells, were able to withdraw their mantle and presumably the whole anterior part of the soft body very deep into their body chambers (Kröger 2002). Therefore, the volume of their soft tissues was less than the volume of their body chambers. The presence of the SCAA gives another piece of evidence that the soft body of spirally coiled ammonites did not fill the entire body chamber volume during active swimming. The SCAA shows that the head complex could have shifted forward to some degree and it should have increased the volume of the mantle cavity, as was assumed by Parent et al. (2014). The ammonites, as representatives of the Cephalopoda, had a mantle cavity. Mutvei \& Reyment (1973) suggested the presence of a mantle cavity with long gills in the ammonoid soft body. Jacobs \& Chamberlain (1996) noted that if ammonoids had large mantle cavities, comparable in size with coleoid mantle cavities, their body chambers might not have been completely filled with soft tissues. When active, the mantle cavity must have been filled with water for ammonite respiration (Fig. 16). Water has a slightly lower density than the cephalopods' soft tissues (Raup \& Chamberlain 1967, Saunders \& Shapiro 1986). Consequently, if a significant part of the volume of the body chamber had been occupied by water, the center of gravity must have been slightly moved towards the aperture (where the denser cephalic region was located), as it was recently suggested (Parent et al. 2014). 
The exact value of the displacement of the center of gravity as well as the impact of the mantle cavity and protrusion of soft tissues through the aperture on the aperture orientation is unknown and requires additional calculations. Several researchers assumed that the density of the ammonoid soft body ( $c a 1.055 \mathrm{~g} / \mathrm{cm}^{3}$ according to Saunders \& Shapiro 1986 and Tajika et al. 2015), was only slightly higher than that of seawater $\left(1.020\right.$ to $\left.1.029 \mathrm{~g} / \mathrm{cm}^{3}\right)$. In this case, the influence of the mantle cavity and the effect of shifting of the head region outside of the body chamber may have been relatively small. The value of ammonoid soft tissue density was obtained according to the density of the Nautilus body, but Jacobs \& Chamberlain (1996) noted that the usage of Nautilus density for ammonoids could be inaccurate as ammonoids are closer to coleoids than to nautilids. Denton \& Gilpin-Brown (1961) pointed out that the density of Sepia tissues on average is $4 \%$ higher than seawater. Similar data ( $4 \%$ and $1.064 \mathrm{~g} / \mathrm{cm}^{3}$ in absolute terms) was published by Arnaya and Sano (1990) for squids Ommastrephes and Todarodes. They also noted that the density of the body is heterogeneous and muscle tissues have a higher density: $1.075 \mathrm{~g} / \mathrm{cm}^{3}$. If the calculations were based on such initial data, the effect of the mantle cavity and of the displacement of tissues would be greater. The weight of the calcified aptychi increases the effect of shifting of the head region outside of the body chamber, but many ammonoids had uncalcified jaws and the impact of their displacement would not have been significant.

\section{Presumable functions of the supracephalic attachment area and of the "protohood"}

The SCAA provides information about the paleobiology of ammonites. However, the most important and interesting question is: what were the functions of the supracephalic attachment area?

\section{Basal function of the dorsal collar attachment}

Among modern Cephalopoda, both the ectocochleate Nautilida and the endocochleate Coleoidea have a special dorsal collar attachment area. In the coleoid soft body, it is the nuchal cartilage, which connects soft tissues with the internal shell in the cephalic region (Bizikov 2008). Naef (1922) described this dorsal nuchal attachment ("collar attachment") as a part of the funnel apparatus. In the Vampyromorpha, Sepiida and Teuthida, the upper margins of collar folds attach to the lateral sides of the nuchal cartilage (Bizikov 2008). In fact, the nuchal cartilage of coleoids connects the funnel with the internal shell. Very likely, the SCAA played a role in ammonoid anatomy similar to that of the nuchal cartilage in coleoids and the black layer in Nautilus (Fig. 17).
The basal function of the collar attachment to the shell on the dorsal side of the body is easy to imagine if we examine the respiratory and locomotion system of the living cephalopods (Bizikov 2002). Collar folds (which are involved in respiration and swimming) must be fixed at the top on the dorsal side to function properly. In Nautilus, a pair of muscular collar folds attach to the visceral sac on the dorsal side. Their anterior parts, visceral sac and posterior part of the hood are fused together behind the head of the Nautilus (see Bizikov 2002, fig. 2B). During embryogenesis and possibly before the formation of the large hood, anterior parts of the collar folds were attached to the dorsal collar extension in ancestors of the Nautilida since in the embryonic soft body, the posterior part of the hood (= dorsal part of the collar), the collar folds and the hyponome represent a single structure (see illustrations of Nautilus embryos in Shigeno et al. 2008, fig. 11a and the cephalopod phylotype in Shigeno et al. 2008, fig. 11c).

However, for the respiratory function of collar folds, a small attachment area not far from the aperture might be quite sufficient (for example as observed in Kosmoceras). I suggest that ammonoid ancestors with straight shells (Orthocerida and Bactritida) might have had a small attachment area directly at the level of the aperture. This suggestion is based on the fact that the wrinkle layer is known from orthoconic shells of some orthocerids and bactritids (Teichert 1964, Mapes 1979, Kröger et al. 2005). Heteromorphic ammonites, whose shells were not tightly coiled on post-embryonic or adult stages of ontogeny (Baculitidae, Ancyloceratidae, Scaphitidae, etc.) also must have had relatively small SCAA on the dorsal part of the aperture since their apertures had no connection with the previous shell whorl. However, the presence of large SCAAs in Sublunuloceras and Pseudocadoceras shells suggests that they have additional functions besides the mantle and collar attachment.

\section{Regulation of aperture orientation}

As discussed above, in the majority of calculations of ammonoid aperture orientation it was assumed that the soft tissues were located only inside the body chamber (Trueman 1941, Raup \& Chamberlain 1967, Saunders \& Shapiro 1986, Klug \& Korn 2004). As a result of these calculations, the apertures of most ammonoid shells were located in a more or less horizontal position (Westermann 1996, fig. 5; Korn \& Klug 2012, figs 5, 6). The presence of the SCAA indicates that the initial postulate of these calculations is erroneous: part of the soft tissues could have been located outside of the body chamber when the animal was active. Nevertheless, in a moment of danger or while resting, when the ammonite soft body was completely withdrawn into the 


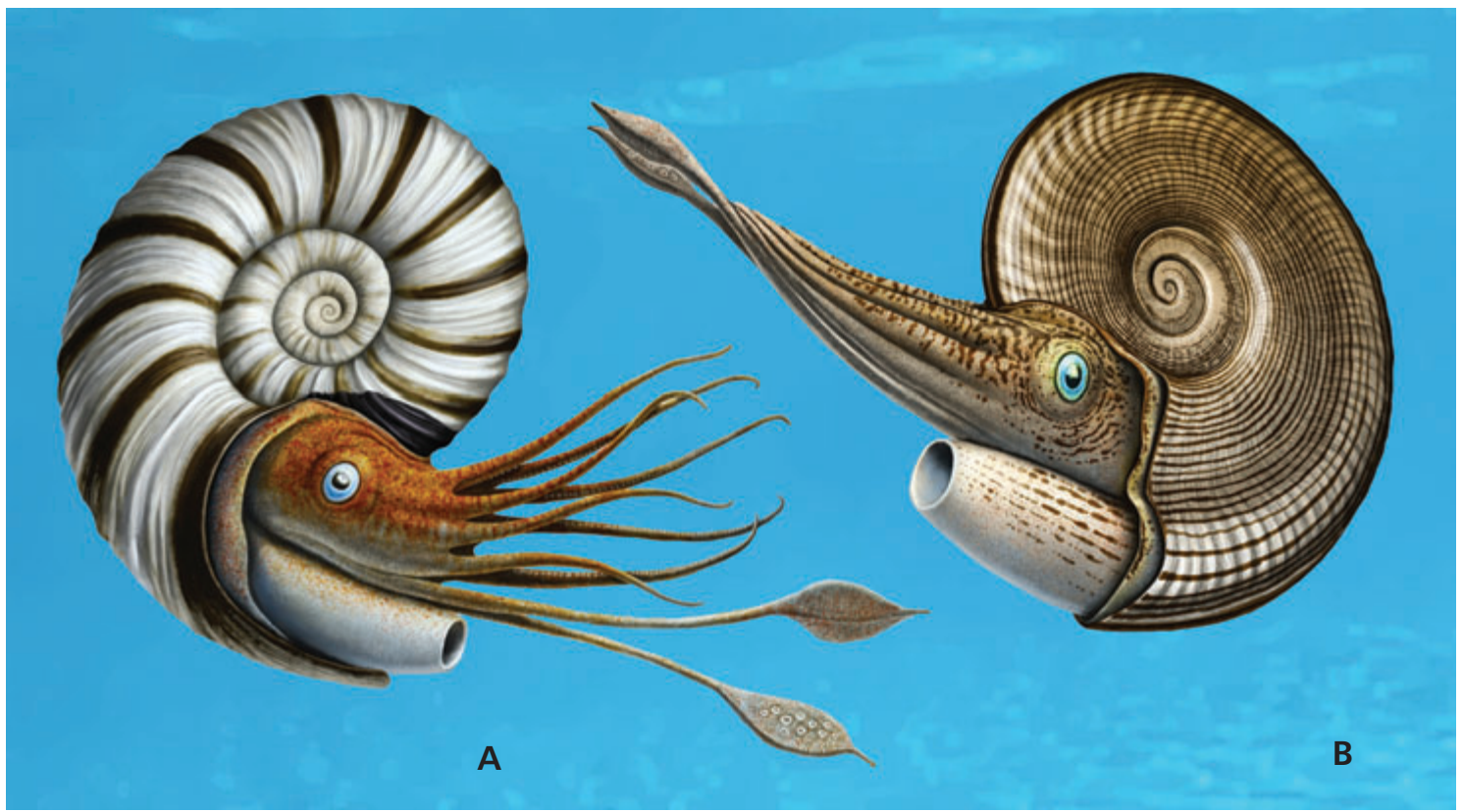

Figure 18. Artistic reconstruction of two Late Callovian ammonites from the Saratov region. A - Quenstedtoceras lamberti. The ammonite is slightly withdrawn into the shell, frightened by the moving Sublunuloceras. The black supracephalic attachment area is partially visible over the head of the ammonite. • B - Sublunuloceras lonsdalii is depicted in the hypothetical position of active funnel-based swimming. Tentacles and arms are stacked together to improve streamlining. Ten arms in both ammonites are shown because Nautilus and representatives of Coleoidea exhibit five arm pairs during early embryonic development, there can be an initial number of arms in Cephalopoda (Shigeno et al. 2008, Kröger et al. 2011). Two long tentacles are very speculative and based on reconstructions in Westermann (1996, fig. 5). The large hyponomes are shown because of the presence of large attachment scars of presumable hyponomic retractors (Doguzhaeva \& Mutvei 1991, 1993a, 1996), and also due to the presence of a large round opening between lappets in several ammonites (Westermann 1954, pl. 9, fig 1, pl. 22, figs 1, 2, pl. 28, figs 1, 8, 1990, fig. 2). The eyes are shown as similar to coleoid eyes because Ammonoidea and Coleoidea were sister taxons (Jacobs \& Landman 1993). This reconstruction was drawn by Andrey Atuchin, based on a sketch from the author of this article.

shell, the aperture likely was oriented in a position which was obtained by calculations (more or less horizontally). Therefore, when the danger had passed, the ammonite would have moved its soft body forward and partially out of the body chamber for active swimming or feeding ( $\mathrm{Pa}-$ rent et al. 2014). If the ammonite's cephalic complex had been large and dense, it might have been capable of turning the whole shell, aperture and phragmocone into an efficient swimming position. However, for greater displacement of the center of gravity a greater displacement of the soft tissues is required. Without connecting to the previous shell whorl, the large cephalic complex of the ammonite would have stuck out of the aperture and the center of gravity would have shifted downward, rather than forward. In order to continue shifting it forward (and continue rotation of the aperture), the soft body must have been connected with the previous whorl in fully coiled ammonoids. The SCAA could have provided this connection.

Therefore, it can be assumed that forward movement of the supracephalic mantle fold, collar, hyponome and head through the aperture - without losing the connection with the dorsal shell wall - could have led to a more or less distinct displacement of the center of gravity of the whole ammonite (Trueman 1941, Parent et al. 2014). In other words, when ammonites kept hold of the previous whorl, the shell would have rotated more or less downward with its body. The angle of this movement, however, remains to be quantified.

Probably, the positive correlation between the length of the SCAA ("black layer") and the body chamber length described by Klug et al. (2004) can be related to this function. A larger cephalic region of the soft body would possibly have required a larger attachment area. As shown above, the correlation between the length of the SCAA and the body chamber length was not observed among ammonites belonging to the genera studied here. Therefore, the difference in size of the SCAA among adult ammonites which belong to one species (or genus) can be explained by this function, but the difference among the various genera might have some other reason.

\section{Optimization of swimming ability}

The measurement of the ammonite shells and their SCAA described herein demonstrate the dependence of the SCAA shape and size on the shell shape. Streamlined oxyconic Sublunuloceras, keeled Quenstedtoceras and discoconic 
Pseudocadoceras have large attachment areas, whereas ammonites with platyconic or serpenticonic shells (Kosmoceras, Binatisphinctes and Peltoceras) have a relatively small SCAA. The smallest areas occur in Kosmoceras shells which bear numerous rows of spines. The shell shape is considered to be strongly connected to swimming ability. Relatively large and middle-sized compressed and involute ammonoid shells have lower drag coefficients than evolute and wide shells during relatively fast locomotion (Westermann 1990, 1996; Jacobs \& Chamberlain 1996). Although the relatively large shell surface of oxyconic shells could have reduced their streamlining, ammonites with such shells were able to accelerate rapidly due to very small "added mass" because of the narrow umbilicus (Jacobs \& Chamberlain 1996). The largest SCAA corresponds to oxyconic and discoconic shell morphologies which were possibly adapted to fast swimming or acceleration (Jacobs \& Chamberlain 1996). Moreover, oxyconic keeled shells not only have the largest, but also the roughest SCAA among the studied she1ls. A rough surface could reinforce the attachment of the soft tissues to the surface (e.g. Keupp 2000). These considerations show that the SCAA had the highest importance for those ammonites, whose shells are streamlined.

It is still unknown how the ammonoid locomotion mechanism was organized - whether it was the powerful and muscular hyponome or velar membranes between ammonite arms or something else. Since so far, the ammonoid soft tissues are only poorly known, the presence of the hyponome in their body is disputable. However, relatively large, rounded and forward oriented openings between the lappets of some microconchs (Westermann 1954, pl. 9, fig. 1, pl. 22, figs 1, 2, pl. 28, figs 1, 8, 1990, fig. 2) are difficult to interpret as something else than openings for large hyponomes. In addition, the presence of a hyponome is indicated by large lateral muscle scars, which are always located closer to the ventral than to the dorsal side (Doguzhaeva \& Mutvei 1991, 1993a, 1996), and by recently described anterior lateral sinuses in front of these muscle scars (Mironenko, in press). The long ventral rostrum of some ammonoids was also interpreted as a support for the hyponome (Doguzhaeva \& Mutvei 1991). Westermann (2013) discussed the presence of a twinnozzled hyponome in several ammonites. By contrast, several Recent cephalopods use a thin membrane between their arms (umbrella) for swimming and ammonites could have used the same method of movement (Westermann, Arkhipkin, pers. comm.), although any evidence for velar membranes in ammonoids is missing.

Several hydrostatic models show that many ammonites had a low rotational stability (Saunders \& Shapiro 1986). However, the actual rotation of the shell depends not only on the rotational stability (estimated as the distance between the centers of mass and buoyancy), but also the point of force direction. If the shell had had a nearly-vertical ori- entation of the aperture (see Parent et al. 2014) and the force had only been applied to the ventral part (where the hyponome must have been located) or to the center of the aperture not far from the venter (if a velar membranes between arms had been the main locomotion apparatus), the shell would have rotated more easily than if the force had been applied at the level of the center of mass (e.g., Korn \& Klug 2004). The bond between the locomotion apparatus and the dorsal shell (through the SCAA in coiled forms) could have allowed to immediately transmit the momentum of propulsive forces to the shell whorl above and behind the locomotion apparatus. Probably it shifted the point of application of force to the shell upward and prevented shell rotation and hence allowed the ammonite to swim at a higher velocity.

Hydrodynamic drag force while swimming forward would have been a problem for ammonites or nautiluses if they had not been attached to the dorsal part of the shell. Water would have put pressure on the phragmocone above the head and the shell would have rotated backward due to counter-flow, while the soft body would have moved forward. However, the shifting of the point of attachment of the soft body forward and upward on the surface of the phragmocone (due to the SCAA) allowed the shell to move forward together with the body and reduced the risk of rotation of the shell from counter-flow.

The author is convinced that ammonoids with planispiral shells had a large muscular hyponome. This hypothesis is supported by its presence in the Recent relatives such as nautilids and coleoids. The locomotion apparatus must have been a part of the soft body and the point of propulsive force application must have been located in the cephalic region of the ammonite. Consequently, the connection between this part of the soft body and the shell was necessary regardless of the type of locomotion apparatus. The hyponome is actually a part of the collar (Naef 1922, Bizikov 2008) and the attachment of the dorsal part of the collar ("protohood") to the SCAA could have created a strong bond between the hyponome and the previous shell whorl. If an umbrella had been the main locomotion apparatus of the ammonoids, the dorsal parts of the collar must have been fused together with the head, but this fusion is common among modern cephalopods (Naef 1922, Bizikov 2008).

It is possible that the transverse wrinkles on the SCAA supported forward movement of the mantle over the wrinkled surface (e.g., Keupp 2000), but also, it may have increased the adhesion of soft tissue to the shell during active swimming (forward or backward) when strong longitudinal physical exertions occurred. The difference in the size and surface structure of the SCAA in different ammonite genera is related with this function. The soft body had to be firmly attached to the shell for active swimming. 


\section{Improving the maneuverability}

If the transverse wrinkles on the SCAA had been associated with the ability to active forward or backward swimming, as discussed above, the question arises: what were the longitudinal wrinkles needed for? Such longitudinal ridges are present on the surface of the SCAA in Sublunuloceras, small wrinkles are located in the SCAA of Quenstedtoceras and Amoeboceras. Similar longitudinal ridges were observed in Amaltheus (Keupp 2000). Most likely, these wrinkles and ridges increased the adhesion of the soft tissues to the shell when the lateral loads occurred during maneuvering. The absence of the SCAA, especially in combination with vertically oriented apertures, would have complicated the maneuvering of the ammonite and its ability to change swimming direction. If the soft body had not been attached to the dorsal shell in front of the aperture, the momentum produced by the locomotion apparatus would have changed the direction of soft body movement whereas the main part of the shell (mainly the phragmocone), above the soft body, would have moved by inertia. This kind of movement would have been extremely ineffective and hardly possible. I assume that for effective jet-propulsion swimming, attachment to the dorsal shell outside of the body chamber was necessary for coiled ammonites. The connection between soft-body, collar and shell allowed ammonites to swim efficiently and to easily change the swimming direction (Fig. 18). This attachment might also have permitted ammonites to change aperture orientation depending on the size and density of soft tissues and the jaw apparatus which all protruded out of the aperture. It appears likely that in different ammonites, these functions varied quite strongly. For some ammonites, the maneuverability was more important, while for others, it was more essential to keep the shell in a certain favorable position. For example, Juvenites septentrionalis (depicted by Keupp 2000 on p. 28) has a long black SCAA on the relatively wide, not very streamlined shell. Juvenites might have rather needed the SCAA primarily to control the shell orientation than for rapid swimming.

\section{Supracephalic attachment area, ventral rostrum and locomotion}

In many ammonoids, the wrinkle layer became thicker when the animal approached adulthood (Klug et al. 2004, Korn et al. 2014). Such thickening can be seen in one of the Quenstedtoceras microconchs (Fig. 7B) and the Binatisphinctes macroconch (Fig. 14A). Kulicki (2001) noted that the area covered by the wrinkle layer outside of the body chamber may exceed the aperture width or be narrower. As discussed above, when the SCAA exceeds aperture width, it indicates ammonite maturity. Korn et al. (2014) sugges- ted that the formation of a very coarse wrinkle layer in adult Early Carboniferous ammonoids were caused by the continuation of the secretion of this layer when longitudinal shell growth had already stopped. In the case of the widening and thickening of the SCAA in adult Jurassic ammonites, the same explanation may apply. Another possible explanation for the size increase of the SCAA after maturation might be the size increase of the cephalic region of ammonites (which requires soft tissue preservation to be proven). Perhaps, the increase in size and thickness of the SCAA could reflect the strengthened connection between soft body and the dorsal shell. It could possibly have increased maneuverability and the swimming speed of ammonites. This assumption is somewhat supported by the fact that young Quenstedtoceras and Pseudocadoceras have short ventral projections (also seen on their temporary apertures, e.g., Fig. $7 \mathrm{~B}_{1}$ ) while mature microconchs of these genera have long ventral rostra (Makowski 1962). Previously, researchers assumed that a ventral rostrum on an ammonoid aperture could have been used to support the large muscular hyponome (Westermann 1990, Doguzhaeva \& Mutvei 1991). Ammonites with a large rostrum (like Sublunuloceras, Quenstedtoceras and Pseudocadoceras) have large SCAAs, whereas Binatisphinctes, Peltoceras and Kosmoceras are lacking a large rostrum and have relatively small SCAAs. If the assumption about the relationship between the size of the SCAA and swimming activity is correct, the same relationship can be assumed for the ventral rostrum. Simultaneous increase in length of the ventral rostrum with the increasing width of the SCAA during maturation may reflect that the activity of microconchs increased at maturity. Nevertheless, evidence for these hypotheses is sparse and particularly, more details of soft tissues are needed to test them. Mathematical models on mass distribution in ammonite shells and soft bodies employing different models for muscle organisation may also shed more light on these questions.

\section{Conclusion}

1. The supracephalic attachment area (SCAA), formed from the wrinkle layer in the apertural region of the ammonoid shell of fully coiled forms, was used for the attachment of the soft body to the penultimate shell whorl outside of the body chamber. Most likely, the supracephalic mantle fold and the dorsal part of the collar ("protohood") had been both attached to this area. In the coleoid soft body, the cephalic cartilage could be considered as a functional analogue of this area.

2. The supracephalic attachment area was probably present in all normally coiled ammonites; its size and surface structure varies greatly among different species. The shape and size of the SCAA and structure of the wrinkles varies depending on shell shape. These variations probably could have had an adaptive value. 
3. Several paleobiological functions of the SCAA can be assumed: the attachment of collar folds to the dorsal shell to facilitate respiration, to regulate shell orientation by controlling the mass of the soft body reaching out of the aperture, optimization of movement and maneuverability due to the connection of the locomotion apparatus to the penultimate shell whorl. However, additional materials with soft tissues and buoyancy calculations are required to test these hypotheses.

4. It appears likely that ammonoids had no hood like Recent Nautilus. The SCAA is not an evidence for the presence of this structure. Instead of the hood, ammonites might have had some kind of "protohood" - a small dorsal extension of the collar, which must have been attached to the SCAA along with a supracephalic mantle fold. However, evidence for the presence of the "protohood" in the ammonoid body can come only from exceptionally preserved ammonoids displaying anatomic detail of this part of the soft body.

5. The supracephalic attachment area indicates the location of a part of the ammonoid soft body outside of the body chamber during active swimming and feeding. Consequently, calculations of the aperture orientation, which were based on the assumption that the entire soft body was always located within the body chamber, are more or less erroneous. The error might vary from negligibly small to major in different ammonoid taxa depending on the density and size of the soft body and especially the jaw apparatus. New calculations are needed which take this protrusion of the soft body through the aperture into account in more detail.

6. Several ammonite microconchs (especially Pseudocadoceras and Quenstedtoceras) show a widening of the supracephalic attachment area, likely after reaching maturity. It might indicate an increase of microconch activity during this stage of their ontogeny. Therefore, the width of the supracephalic attachment area could become useful as a mature character.

7. The supracephalic attachment area indicates that ammonoids had an external shell which was usually not completely covered with a mantle.

\section{Acknowledgments}

I am very grateful to Andrey Devyatkin, Roman Stredinin (both from Saratov, Russia) and Dmitry Vinogradov (Moscow, Russia) for the donation of specimens for this study. Many thanks to Vyacheslav Bizikov (Russian Federal Research Institute of Fisheries and Oceanography -VNIRO, Moscow) for important advice on the anatomy of modern Cephalopoda and for Michail Rogov (Geological Institute of the Russian Academy of Sciences - GIN RAS, Moscow) for a great help in gathering the paleontological literature. Special thanks to the administration of the Moscow Children's Ecological and Biological Center and to Maksim Boiko (Paleontological Institute of Russian Academy of Sciences (PIN RAS), Moscow) for the opportunity to inspect the ammonite collection of this Center. The author is grateful to amateur paleontologist Alexey Homenko (Moscow, Russia) for the opportunity to study his collection. Christian Klug (Zürich, Switzerland), René Hoffmann (Bochum, Germany) and Dieter Korn (Berlin, Germany) contributed considerably for improving the paper as reviewers of the journal. SEM photos were made through help by Roman Rakitov (PIN RAS, Moscow, Russia). Very accurate and beautiful reconstructions of ammonites based on my sketch were drawn by paleoillustrator Andrey Atuchin (Kemerovo, Russia). Special thanks to Steve Ford (Vancouver, Canada) who went over and edited the manuscript with me to improve language.

\section{References}

Andrew, C., Howe, P., Paul, C.R.C. \& Donovan, S.K. 2011. Epifaunal worm tubes on Lower Jurassic (Lower Lias) ammonites from Dorset. Proceedings of the Geologists' Association 122, 34-46.

Arnaya, I.N. \& Sano, N. 1990. Studies on acoustic target strength of squid. V. Effect of swimming on target strength of squid. Bulletin of the Faculty of Fisheries, Hokkaido University 41, 18-31.

BAYER, U. 1974. Die Runzelschicht - ein Leichtbauelement der Ammonitenschale. Paläontologische Zeitschrift 48, 6-15. DOI 10.1007/BF02986986

BirKelund, T. 1981. Ammonoid shell structure, 177-214. In House, M.R. \& SEnIor, J.R. (eds) The Ammonoidea. The Systematic Association, Special Volume 18.

BizıKov, V.A. 2002. Reanalysis of functional design of Nautilus locomotory and respiratory system. American Malacological Bulletin 17, 17-30.

Bizikov, V.A. 2008. Evolution of the shell in Cephalopoda. 444 pp. VNIRO Publishing, Moscow.

Denton, E.J. \& Gilpin-Brown, J.B. 1961. The buoyancy of the cuttlefish, Sepia officinalis (L). Journal of the Marine Biological Association of the United Kingdom 41(2), 319-342. DOI 10.1017/S0025315400023948

DoguZhaeva, L.A. 1981. Wrinkle layer of ammonoid shell. Paleontological Journal 1, 38-48. [in Russian]

Doguzhaeva, L.A. 2012. Functional significance of parabolae, interpreted on the basis of shell morphology, ultrastructure and chemical analyses of the Callovian ammonite Indosphinctes (Ammonoidea: Perisphinctidae), Central Russia. Revue de Paléobiologie 11, 89-101.

Doguzhaeva, L.A. \& Mutvei, H. 1986. Functional interpretation of inner shell layers in Triassic ceratitid ammonites. Lethaia 19, 195-209. DOI 10.1111/j.1502-3931.1986.tb00732.x

Doguzhaeva, L.A. \& Mutvei, H. 1991. Organization of the soft body in Aconeceras (Ammonitina), interpreted on the basis of shell morphology and muscle scars. Palaeontographica, Abteilung A 218, 17-33.

Doguzhaeva, L.A. \& Mutvei, H. 1993a. Shell ultrastructure, muscle scars, and buccal apparatus in ammonoids. Cephalopods - Present and Past. $3^{\text {rd }}$ International Cephalopod Symposium, 17-21 July 1990, Lyon, France. Geobios, Memoire special 26, 111-119. DOI 10.1016/S0016-6995(06)80366-9

Doguzhaeva, L.A. \& Mutvei, H. 1993b. Structural features of 
Cretaceous ammonoids indicative of semi-internal or internal shells, 99-114. In House, M.R. (ed.) The Ammonoidea: Environment, Ecology, and Evolutionary Change, Systematics Association, Special Volume 47.

Doguzhaeva, L.A. \& Mutvei, H. 1996. Attachment of the body to the shell in ammonoids, 43-63. In Landman, N., TANABE, K. \& Davis, R.A. (eds) Ammonoid Paleobiology. Topics in Geobiology 13. Plenum Press, New York.

Drushchits, V.V., Doguzhaeva, L.A. \& Mikhailova, I.A. 1978. Unusual coating layers in ammonites. Paleontological Journal 2, 36-44. [in Russian]

ENGESER, T. \& Keupp, H. 2002. Phylogeny of the aptychi-possessing Neoammonoidea (Aptychophora nov., Cephalopoda). Lethaia 34, 79-96. DOI 10.1080/002411602317345894

GŁowniak, E. \& WierzBowski, A. 2007. Taxonomical revision of the perisphinctid ammonites of the Upper Jurassic (Plicatilis to Planula zones) described by Józef Siemiradzki (1891) from the Kraków Upland. Volumina Jurassica 5, 27-137.

GRIFFIN, L.E. 1900. The anatomy of Nautilus pompilius. Memoirs of the National Academy of Sciences 8, 101-230.

House, M.R. 1971. The goniatite wrinkle-layer. Smithsonian Contribution to Paleobiology 3, 23-32.

JACOBS, D. K. \& LANDMAN, N.H. 1993. Nautilus - a poor model for the function and behavior of ammonoids? Lethaia 26, 101-111. DOI 10.1111/j.1502-3931.1993.tb01799.x

JACOBS, D.K. \& Chamberlain, J.A. 1996. Buoyancy and hydrodynamics in ammonoids, 169-223. In LANDMAN, N., TANABE, K. \& Davis, R.A. (eds) Ammonoid Paleobiology. Topics in Geobiology 13. Plenum Press, New York.

Keupp, H. 1973. Der Wert anomaler Perisphincten (Ammonoidea) für die Deutung der Parabelgenese. Geologischen Blätter für Nordost-Bayern 23(1), 20-35.

Keupp, H. 2000. Ammoniten. Paläobiologische Erfolgsspiralen. 165 pp. Thorbecke Species, Stuttgart.

Keupp, H. \& MitTA, V. 2013. Cephalopod jaws from the Middle Jurassic of central Russia. Neues Jahrbuch für Geologie und Paläontologie 270(1), 23-54. DOI 10.1127/0077-7749/2013/0356

Kiselev, D., Rogov, M., Glinskikh, L., Guzhikov, A., Pimenov, M., Mikhailov, A., Dzyuba, O., Matveev, A. \& Tesakova, E. 2013. Integrated stratigraphy of the reference sections for the Callovian/Oxfordian boundary in European Russia. Volumina Jurassica 11, 59-96.

KLUG, C. 2004. Mature modifications, the black band, the black aperture, the black stripe, and the periostracum in cephalopods from the Upper Muschelkalk (Middle Triassic, Germany). Mitteilungen aus dem Geologisch-Palaontologischen Institut der Universitat Hamburg 88, 63-78.

Klug, C., Brühwiler, T., Korn, D., Schweigert, G., Brayard, A. \& Tilsey, J. 2007. Ammonoid shell structures of primary organic composition. Palaeontology 50(6), 1463-1478. DOI 10.1111/j.1475-4983.2007.00722.x

KLUG, C. \& Korn, D. 2004. The origin of ammonoid locomotion. Acta Palaeontologica Polonica 49(2), 235-242.

Klug, C., Korn, D., Richter, U. \& UrLichs, M. 2004. The black layer in cephalopods from the German Muschelkalk (Middle Triassic). Palaeontology 47(6), 1407-1425. DOI 10.1111/j.0031-0239.2004.00422.x

Klug, C., Riegraf, W. \& Lehmann, J. 2012. Soft-part preserva- tion in heteromorph ammonites from the CenomanianTuronian Boundary Event (OAE 2) in the Teutoburger Wald (Germany). Palaeontology 55(6), 1307-1331.

KorN, D. 1985. Runzelschicht und Ritzstreifung bei Clymenien (Ammonoidea, Cephalopoda). Neues Jahrbuch für Geologie und Paläontologie, Monatshefte 9, 533-541.

Korn, D. 2000. Mantle expansion upon the conch in the Late Devonian ammonoid Erfoudites. Acta Geologica Polonica 50(1), 21-27.

Korn, D. \& KluG, C. 2012. Palaeozoic ammonoids - diversity and development of conch morphology, 491-534. In TALENT, J.A. (ed.) Earth and Life. Springer, Dordrecht.

Korn, D., Klug, C. \& Mapes, R.H. 2014. The coarse wrinkle layer of Palaeozoic ammonoids: new evidence from the Early Carboniferous of Morocco. Palaeontology 57, 771-781.

DOI 10.1111/pala.12087

KRÖGER, B. 2002. On the ability of withdrawing of some Jurassic ammonoids, 199-204. In Summesberger, H., Histon, K. \& DAurer, A. (eds) Cephalopods-present and past. Abhandlungen der Geologischen Bundesanstalt Wien 57.

KröGER, B., KLUG, C. \& MAPES, R. 2005. Soft-tissue attachments in orthocerid and bactritid cephalopods from the Early and Middle Devonian of Germany and Morocco. Acta Palaeontologica Polonica 50(2), 329-342.

Kröger, B., Vinther, J. \& Fuchs, D. 2011. Cephalopod origin and evolution: A congruent picture emerging from fossils, development and molecules. Bioessays 33, 602-613. DOI 10.1002/bies.201100001

KULICKI, C. 1979. The ammonite shell: its structure, development and biological significance. Acta Palaeontologica Polonica $39,97-142$.

Kulicki, C., Tanabe, K., Landman, N.H. \& Mapes, R.H. 2001. Dorsal shell wall in ammonoids. Acta Palaeontologica Polonica 46(1), 23-42.

LARSOn, N.L. 2007. Deformities in the Late Callovian (Late Middle Jurassic) ammonite fauna from Saratov, Russia, 344-374. In LANDMAN, N.H., DAvis, R.A. \& MAPES, R.H. (eds) Cephalopods present and past: new insights and fresh perspectives. Springer, New York.

Lehmann, J., KLug, C. \& Wild, F. 2014. Did ammonoids possess opercula? Reassessment of phosphatised soft tissues in Glaphyrites from Uruguay. Paläontologische Zeitschrift, 1-15. DOI 10.1007/s12542-013-0219-8

Lehmann, U. 1972. Aptychen als Kieferelemente der Ammoniten. Paläontologische Zeitschrift 46(1/2), 34-48. DOI 10.1007/BF02989550

Lehmann, U. \& Kulicki, C. 1990. Double function of aptychus (Ammonoidea) as jaw elements and opercula. Lethaia 23, 325-331. DOI 10.1111/j.1502-3931.1990.tb01365.x

Makowski, H. 1962. Problem of sexual dimorphism in ammonites. Palaeontologia Polonica 12, 1-92.

MAPES, R.H. 1979. Carboniferous and Permian Bactritoidea (Cephalopoda) in North America. University of Kansas Paleontological Contribution 64, 1-75.

MAPES, R.H. \& DAVIS, R.A. 1996. Color patterns in ammonoids, 104-127. In Landman, N., Tanabe, K. \& Davis, R.A. (eds) Ammonoid Paleobiology. Topics in Geobiology 13. Plenum Press, New York.

MERKT, J. 1966. Über Euagassiceras resupinatum (Simpson), 
Ammonoidea, aus der Sauzeanumbank Nordwestdeutschlands. Geologisches Jahrbuch 84, 23-88.

Mironenko, A.A. (in press). The soft-tissue attachment scars in Late Jurassic ammonites from Central Russia. Acta Palaeontologica Polonica. DOI 10.4202/app.00041.2013

Mitta, V.V. \& Keupp, H. 2004. Ammoniten-Kiefer aus dem Callovium Russlands. Mitteilungen aus dem GeologischPaläontologischen Institut der Universität Hamburg 88, 125-134.

Monks, N. \& Young, J.R. 1998. Body position and the functional morphology of Cretaceous heteromorph ammonites. Palaeontologia Electronica 1(1), 1A, $15 \mathrm{pp}$.

Mutvei, H. \& Reyment, R.A. 1973. Buoyancy control and siphuncle function in ammonoids. Palaeontology 16, 623-636.

NAEF, A. 1922 (2004). Fossil dibranchiate cephalopods. Berliner Paläobiologische Abhandlungen 5, 1-209 [Translated from German: Die Fossilen Tintenfische - Eine paläozoologische Monographie. 322 pp. G. Fischer, Jena.]

Naglik, C., Monnet, C., Goetz, S., Kolb, C., De Baets, K., TAJIKA, A. \& KLUG, C. 2014. Growth trajectories of some major ammonoid sub-clades revealed by serial grinding tomography data. Lethaia 48(1), 29-46. DOI 10.1111/let.12085

NAssichuK, W.W. 1967. A morphological character new to ammonoids portrayed by Clistoceras gen. nov. from Pennsylvanian of Arctic Canada. Journal of Paleontology 41, 237-242.

Parent, H., Westermann, G.E.G. \& Chamberlain, J.A. JR. 2014. Ammonite aptychi: Functions and role in propulsion. Geobios 47, 45-55. DOI 10.1016/j.geobios.2013.12.001

Quenstedt, F.A. 1845-1849. Petrefactenkunde Deutschlands. Erste Abtheilung. Erster Band. Cephalopoden. 580 pp. L.F. Fues, Tübingen.

Raup, D.M. 1966. Geometric analysis of shell coiling. General problems. Journal of Paleontology 40, 1178-1190.

RAUP, D.M. 1967. Geometric analysis of shell coiling: coiling in ammonoids. Journal of Paleontology 47(1), 43-65.

RAUP, D.M. \& ChAmberlain, J.A. JR. 1967. Equations for volume and center of gravity in ammonoid shells. Journal of Paleontology 41, 566-574.

Rogov, M.A. 2004. Middle and Late Callovian Aptychi (Ammonoidea) of the Russian Plate. Paleontological Journal 38(1), 27-34.

Rogov, M.A. \& Gulyaev, D.B. 2003. On the first find of aptychi in representatives of the subfamily Proplanulitinae Buckman (Perisphinctidae, Ammonitida). Paleontological Journal 37(4), 382-385.

SANDBERGER, G. 1851. Beobachtungen über mehrere schwierige Puncte der Organisation der Goniatiten. Jahrbücher des Vereins für Naturkunde im Herzogthum Nassau 7, 292-304.

SAUNDERS, W.B. \& SHAPIRO, E.A. 1986. Calculation and simulation of ammonoid hydrostatics. Paleobiology 12, 64-79.

Schmid, H. 1930. Ober die Bewegungsweise der Cephalopoden. Paläontologische Zeitschrift 12, 194-207.

DOI 10.1007/BF03044449

SchweIGert, G. 2000. Über den Aptychus der mitteljurassischen Ammonitengattung Kosmoceras. Neues Jahrbuch für Geologie und Paläontologie, Monatshefte 11, 698-704.
Seltzer, V.B. 1999. New locality of the Callovian-Lower Oxfordian ammonite fauna in the Saratov Volga area. In Problems of the geoecology of Saratov and Saratov province, Saratov 3, 102-107. [in Russian]

SENIOR, J.R. 1971. Wrinkle-layer structures in Jurassic ammonites. Palaeontology 14, 107-113.

Shigeno, S., Sasaki, T., Moritaki, T., Kasugai, T., Vecchione, M. \& AGatA, K. 2008. Evolution of the cephalopod head complex by assembly of multiple molluscan body parts: evidence from Nautilus embryonic development. Journal of Morphology 269, 1-17. DOI 10.1002/jmor.10564

TajiKa, A., Naglik, C., Morimoto, N., Pascual-Cebrian, E., HENNHÖFER, D.K. \& KLUG, C. 2015. Empirical 3D-model of the conch of the Middle Jurassic ammonite microconch Normannites, its buoyancy, the physical effects of its mature modifications and speculations on their function. Historical Biology 27(2), 181-191. DOI 10.1080/08912963.2013.872097

TeICHERT, C. 1964. Morphology of hard parts, K13-K59. In Moore, R.C. (ed.) Treatise on Invertebrate Paleontology, Part K, Mollusca 3, Cephalopoda-General Features-Endoceratoidea-Actinoceratoidea-Nautiloidea-Bactritoidea. Geological Society of America \& University of Kansas Press, Boulder \& Lawrence.

TozER, E.T. 1972. Observations on the shell structure of Triassic ammonoids. Palaeontology 15, 637-654.

Trueman, A.E. 1941. The ammonite body-chamber, with special reference to the buoyancy and mode of life of the living ammonite. Quarterly Journal of the Geological Society, London 96, 339-383.

DOI 10.1144/GSL.JGS.1940.096.01-04.14

TureK, V. 1975. Genus Kosovoceras gen. n. in the Silurian of Central Bohemia (Nautiloidea). Sborník geologických věd, Paleontologie 17, 7-42.

WALliser, O.H. 1970. Über die Runzelschicht bei Ammonoidea. Göttinger Arbeiten zur Geologie/Pälaontologie (H. MartinFestschrift) 5, 115-126.

WARD, P.D. \& SAUNDERs, W.B. 1997. Allonautilus: a new genus of living nautiloid cephalopods and its bearing on phylogeny of the Nautilida. Journal of Paleontology 71, 1054-1064.

Westermann, G.E.G. 1954. Monographie der Otoitidae (Ammonoidea). Beihefte zum Geologischen Jahrbuch 15, 1-364.

Westermann, G.E.G. 1996. Ammonoid life and habitat, 607-707. In Landman, N., Tanabe, K. \& Davis, R.A. (eds) Ammonoid Paleobiology. Topics in Geobiology 13. Plenum Press, New York.

Westermann, G.E.G. 2013. Hydrostatics, propulsion and lifehabits of the Cretaceous ammonoid Baculites. Revue de Paléobiologie 32, 249-265.

Westermann, G.E.G. \& Tsujita, C.J. 1999. Life habits of ammonoids, 299-325. In SAvAzzi, E. (ed.) Functional Morphology of the Invertebrate Skeleton. John Wiley \& Sons, New York.

ZaKharov, Y.D. \& GrabovsKaYa, B.S. 1984. Shell structure in the genus Zelandites (Lytoceratida). Paleontological Journal 1, 19-29. [in Russian]

ZatoŃ, M. 2010. Sublethal injuries in Middle Jurassic ammonite shells from Poland. Geobios 43, 365-375.

DOI 10.1016/j.geobios.2009.11.004 